\title{
Scientific rationale of Indian AYUSH Ministry advisory for COVID-19 prevention, prophylaxis, and immunomodulation
}

\author{
Prashant Kumar Gupta ${ }^{1} \cdot$ Kishor Sonewane $^{1} \cdot$ Mariappan Rajan $^{2} \cdot$ Nitin J. Patil $^{3} \cdot$ Trapti Agrawal $^{4} \cdot$ Ena Ray Banerjee $^{5}$. \\ Nagendra Singh Chauhan ${ }^{6}$. Awanish Kumar ${ }^{7}$ (i)
}

Received: 18 December 2020 / Accepted: 28 March 2021

(c) Institute of Korean Medicine, Kyung Hee University 2021

\begin{abstract}
The current outbreak of COVID-19 is caused by the SARS-CoV-2 virus that has affected $>210$ countries. Various steps are taken by different countries to tackle the current war-like health situation. In India, the Ministry of AYUSH released a self-care advisory for immunomodulation measures during the COVID-19 and this review article discusses the detailed scientific rationale associated with this advisory. Authors have spotted and presented in-depth insight of advisory in terms of immunomodulatory, antiviral, antibacterial, co-morbidity associated actions, and their probable mechanism of action. Immunomodulatory actions of advised herbs with no significant adverse drug reaction/toxicity strongly support the extension of advisory for COVID-19 prevention, prophylaxis, mitigations, and rehabilitation capacities. This advisory also emphasized Dhyana (meditation) and Yogasanas as a holistic approach in enhancing immunity, mental health, and quality of life. The present review may open-up new meadows for research and can provide better conceptual leads for future researches in immunomodulation, antiviral-development, psychoneuroimmunology, especially for COVID-19.
\end{abstract}

Keywords COVID-19 $\cdot$ Indian AYUSH advisory $\cdot$ Ayurveda $\cdot$ Immunomodulation $\cdot$ Therapy

Awanish Kumar

drawanishkr@gmail.com; awanik.bt@nitrr.ac.in

1 Department of Balroga, Shri NPA Govt. Ayurveda College, Raipur (CG), India

2 Department of Natural Product Chemistry, Madurai Kamaraj University, Madurai, Tamil Nadu, India

3 Department of Integrative Medicine, Sri Devraj Urs Academy of Higher Education and Research, Kolar, Karnataka, India

4 Department of Stri Roga \& Prasuti Tantra, Chaudhary Brahm Prakash Ayurved Charak Sansthan, New Delhi, India

5 Department of Zoology, Immunology and Regenerative Medicine Research Unit, University of Calcutta, Kolkata, India

6 Drugs Testing Laboratory Avam Anusandhan Kendra (State Government Lab of AYUSH), Government Ayurvedic College, Raipur (CG), India

7 Department of Biotechnology, National Institute of Technology, Raipur (CG) 492010, India

\section{Introduction}

Today whole world is battling with the current pandemic of COVID-19 (Corona Virus Disease-2019). Increasing patient trend, high extend of spread, the unpredictability of manifestation of the clinical disease spectrum, and the uncertainty of cure are some worrisome concerns behind such social and mental stress in COVID-19. Information on COVID-19 is evolving very fast and it unlikely to have any definite treatment in near future. Drug discovery is a costly and large gestational affair while repurposing can cut short both cost/gestational time and bypass the preclinical and safety studies hence a push for Hydroxychloroquine repurposing is emphasized and exhibiting with a mixed response from scientists and clinicians (Rodrigo et al. 2020). Amid such situations, where modern medical science and traditional medicine are standing on the same platform, we must explore all possibilities to prevent, mitigate, and control this pandemic. It is the right time to integrate critical care and complication management skills of allopathy and preventive, immunomodulatory, and mental health management through traditional medicine. The development of traditional medicine with the perspectives 
of safety, efficacy, and quality would help not only to preserve the traditional heritage but also to rationalize the use of herbal medicine in human healthcare (Mukharjee et al. 2017). Integration of traditional Chinese medicine and modern medicine had formed the dominant treatment strategy in all COVID-19 affected areas across China (Jia and Yunfei 2020). Following a rich heritage of traditional medicine, the Indian AYUSH (Ayurveda, Yoga, Unani, Sidha, and Homeopathy) ministry has released an advisory for preventive health and immunity-boosting measures for self-care during the COVID-19 crisis (https://ayush.gov. in). It underscores the concept of "Prevention is better than cure".

The author has screened the capacity of AYUSH-advisory in the prevention, prophylaxis, mitigations, and rehabilitation of COVID-19 cases. Advisory broadly divided into 3 categories i.e. general measures, immunity promotive measures, and the Ayurveda procedures to follow. General measures of advisory advocate drinking warm water throughout the day in COVID-19 outbreak and practice of Yogasana, Pranayaam, and Dhayana (meditation) for $30 \mathrm{~min}$ daily (https://ayush.gov.in). According to Ayurveda, drinking hot water helps in digesting Aama (a proinflammatory marker of impaired metabolism) followed by Samprapti Vighatan (break of disease cascade). It is advocated in Naveen Jwara (fever) (Vaidya and Trikamji 2004). It is a good natural remedy to treat nasal congestion. A clinical study done in 15 healthy subjects, the nasal mucus velocity was measured before and at 5 and $30 \mathrm{~min}$ after drinking hot water increased from 6.2 to $8.4 \mathrm{~mm} /$ min five minutes after administration in patients drinking hot water by sip, again value returned to their baseline at $30 \mathrm{~min}$. The above study concludes increased nasal mucus velocity might be helpful in the management of upper respiratory tract infections (Saketkhoo et al. 1978).

On the line of advisory, the author emphasized how Yoga, Dhyana, and Pranayaam practices can be helpful in fighting psychoneuroimmuno perturbation during COVID19. Among general measures, Yoga therapy is a form of mind-body medicine that integrates an individual's physical, psychological, social, and spiritual components to enhance health, with a primary focus on stress and related illnesses (Atkinson and Permuth-Levine 2009). Yoga therapy comprises yogic physical postures (Asanas), Yogic breathing techniques (Pranayama), meditation (Dhyana)/ Mindfulness, Yogic cleansing techniques (Kriya), Yogic gestures (Mudras), and locks (Bandhas) (Sengupta 2012). Evidence suggests Yoga as a therapeutic tool in alleviating fear, depression, anxiety, negative thinking, and enhance the quality of sleep (Cabral et al. 2011). With mounting scientific literature/research in the field of Yoga, it is regarded as a form of Complementary and Alternative
Medicine (CAM) by National Centre for Complementary and Integrative Health (NCCIH), USA.

Spices like Curcumin longa Linn. (Haldi), Cuminum cyminum Linn. (Jeera), Coriandrum sativum Linn. (Dhaanyaka), and Allium sativum Linn. (Lahsun) are recommended for cooking. Herbal medicines like Ocimum sanctum Linn. (Tulsi), Piper nigrum Linn. (Maricha), Dry Zingiber officinale Roscoe (Shunthi), Cinnamomum species (Tvaka), Dry Vitis vinifera Linn. (Munnaka, Raisin, dried grapes) are recommended to make herbal tea/decoction and consume twice daily. Chyawanprasha (Herbo-mineral ayurvedic preparation) $10 \mathrm{~g}$ daily in the morning is also advised (https://ayush. gov.in). Herbal drug screening revealed the presence of phytoconstituents such as polyphenol, terpenoid, flavonoid, curcumin, anthocyanin, proteins like lectins or agglutinins, piperine, vitamin $\mathrm{C}$, gingerols, anthraquinone, and so on. These phytochemicals showed wide pharmacological actions but here we are documenting immunomodulatory, antiviral, and antibacterial actions, co-morbidity preventive action, and their probable mechanism of action.

The third section i.e. Ayurvedic procedures advocates oil pulling therapy (Kawala) by sesame or coconut oil for 2-3 min followed by the warm water rinse, nasal application (Pratimarsh Nasya) of sesame oil or coconut oil or ghee in morning and evening. Daily steam inhalation with Mentha arvensis Linn. (Pudina) or Trachyspermum ammi Linn. (Ajwain), and Syzigium aromaticum Linn. (lavang) powder with honey orally is advised for ailment like sore throat or cough (ayush.gov.in). Recently, Indian states like Kerala, Delhi, Gujarat, Goa, and so on, allowed to treat COVID19 confirm cases through dedicated Ayurveda/integrative approach using Ayurveda and modern medicine through projects like 'Sukhayusham,' 'Swasthyam,' and 'AyurRaksha' clinics. The herbal medicines and Ayurveda procedures mentioned in the advisory are being used for the purpose of immunomodulation, antimicrobial, and stress management in various traditional medicine the system of the world since ancient period (Table 1). In the next section, AYUSH recommended herbs, their present antimicrobial, immunomodulatory, and antiviral actions are discussed in detail and how these medicines and procedures are vindicated in retaliation of COVID-19.

\section{Immunomodulatory and antimicrobial actions of herbs advised by Indian Ayush Ministry}

The current advisory supports the scientific background of Ayurvedic plants and their phytochemicals support the immune system and have antimicrobial action (Fig. 1a,b). Apart from that, we have also discussed the detailed role of advised herbs because each phytochemical influences 


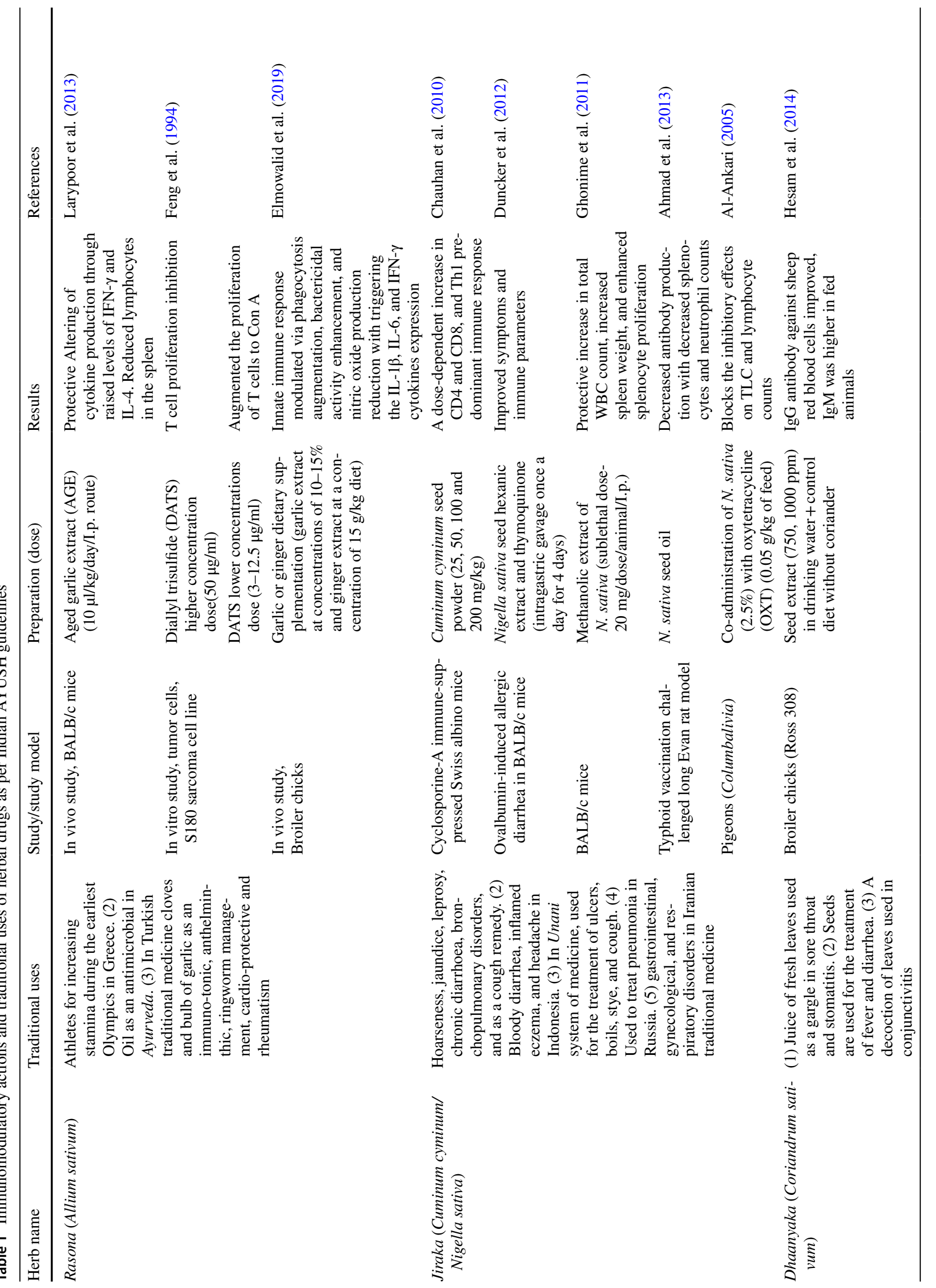




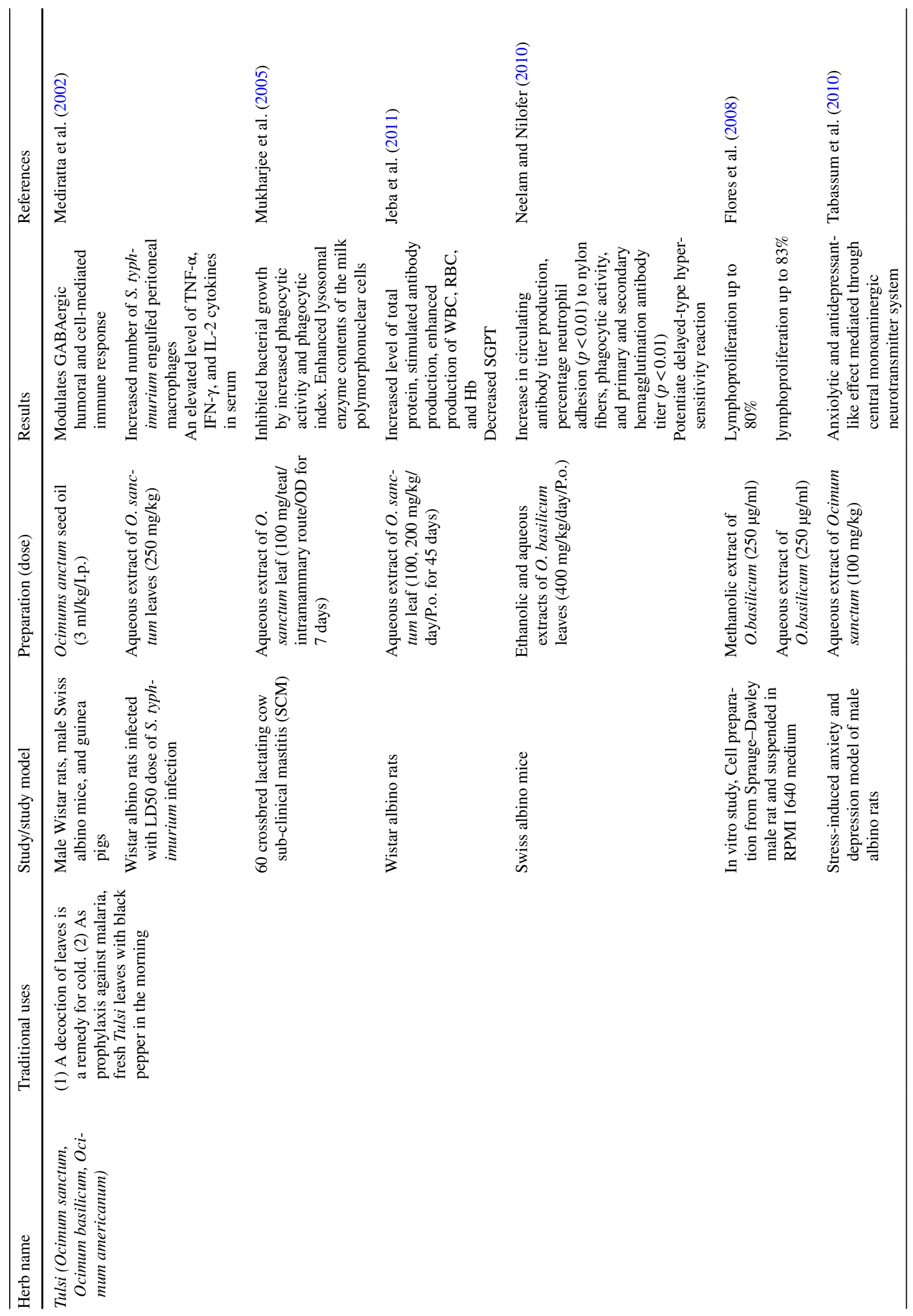




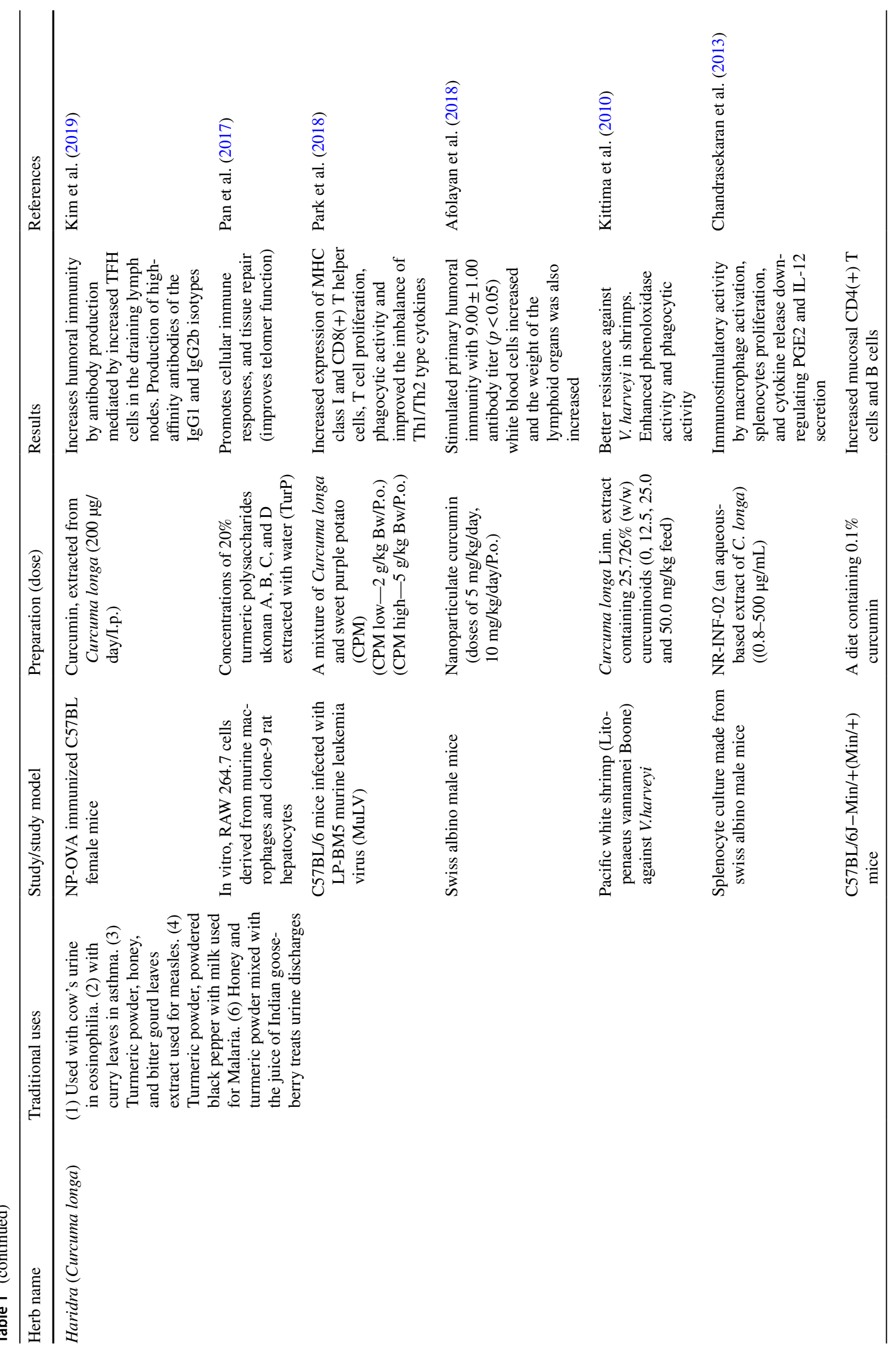




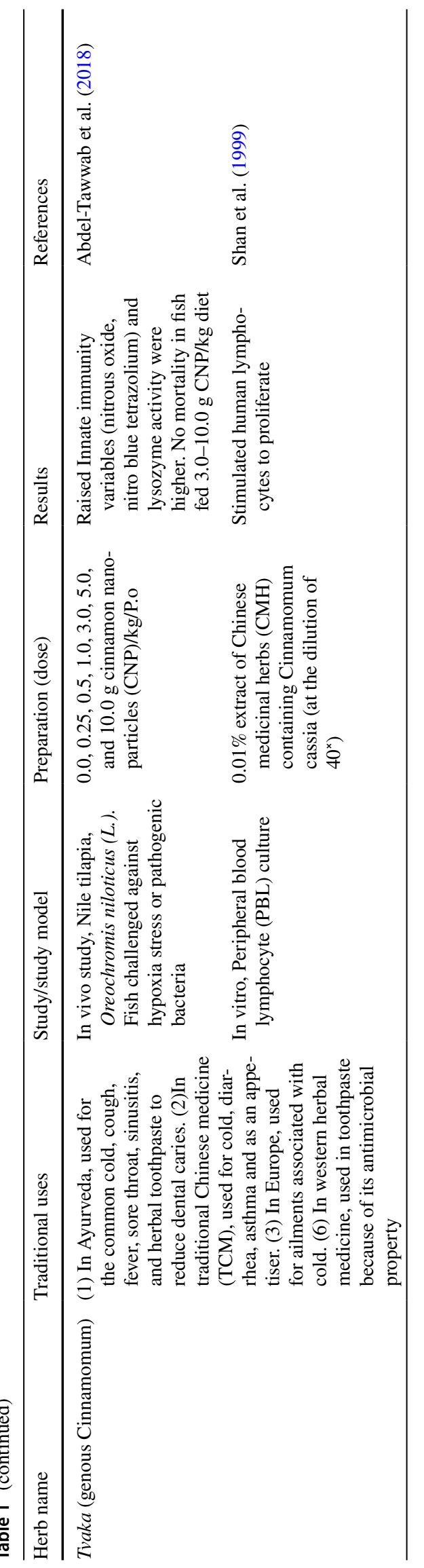

Springer 


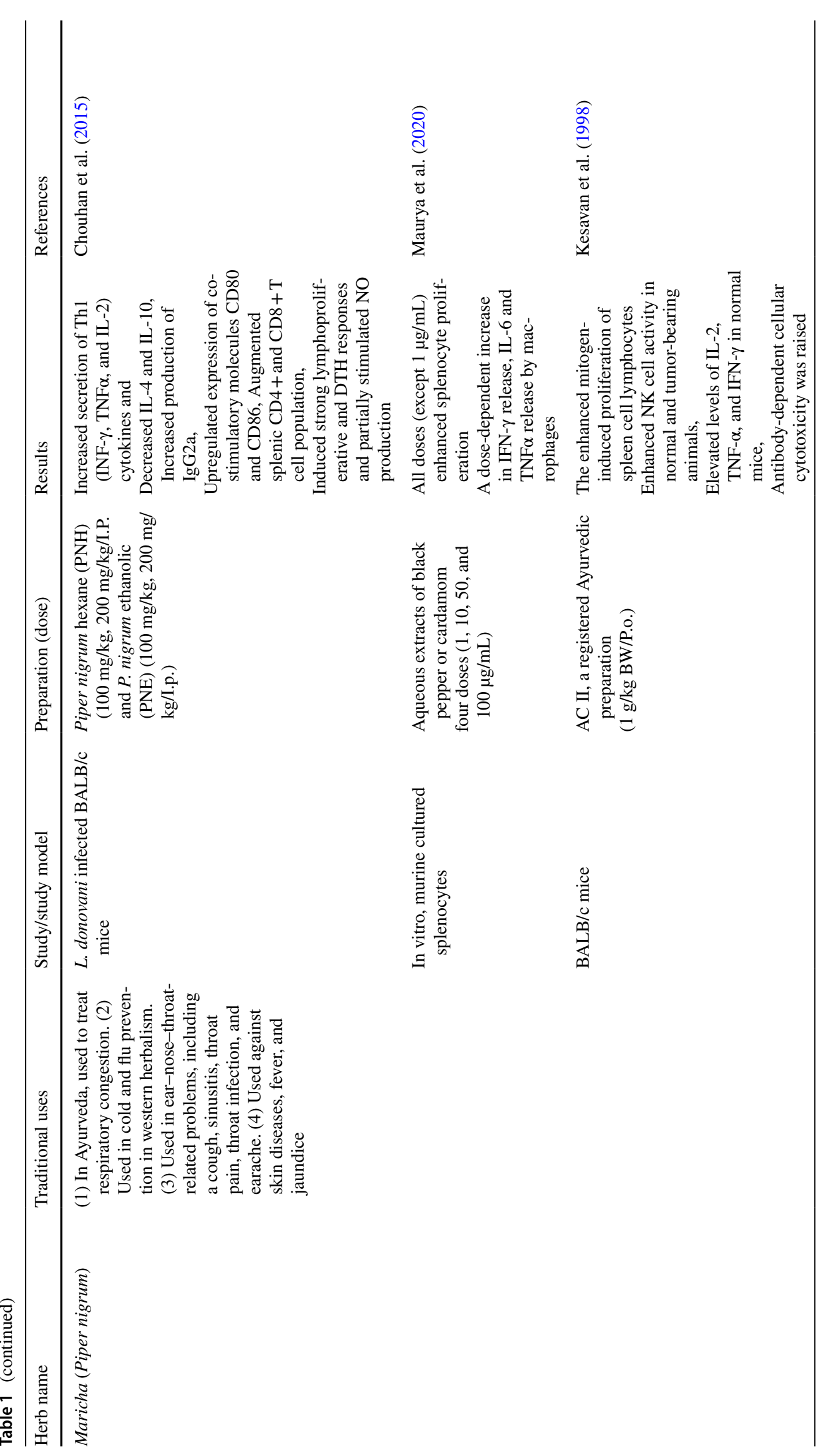




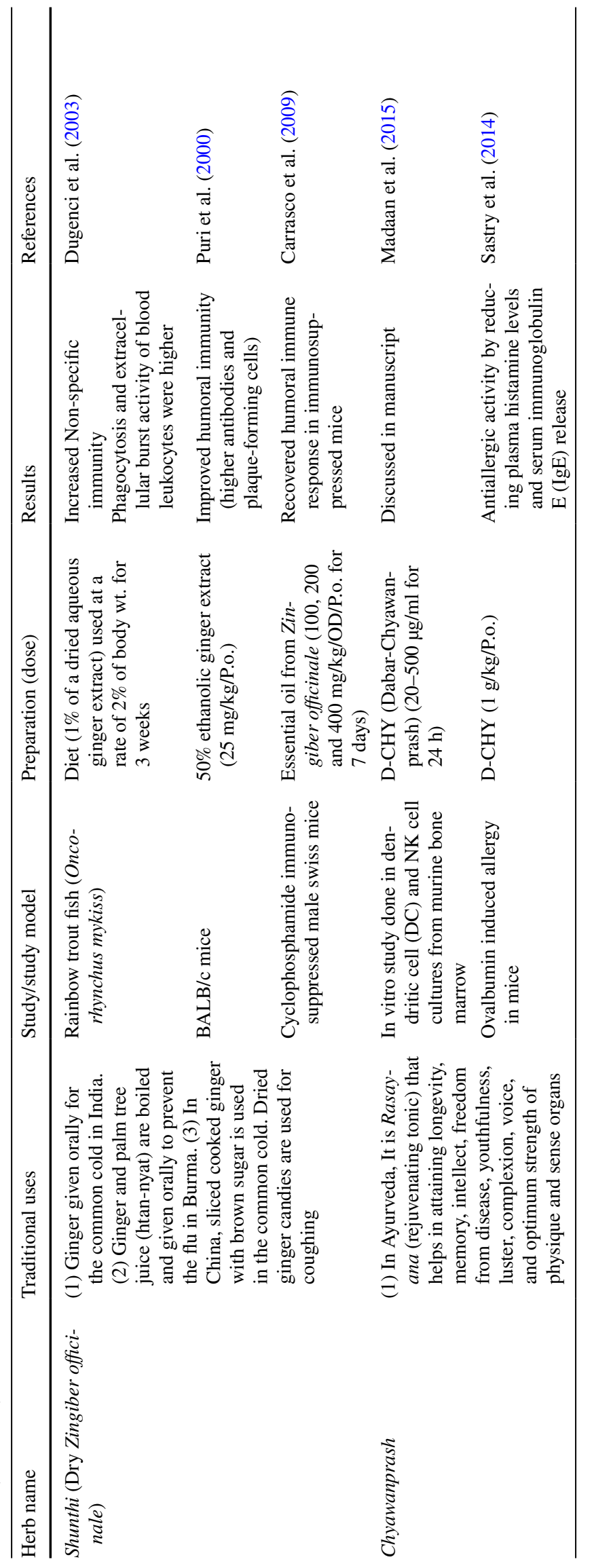




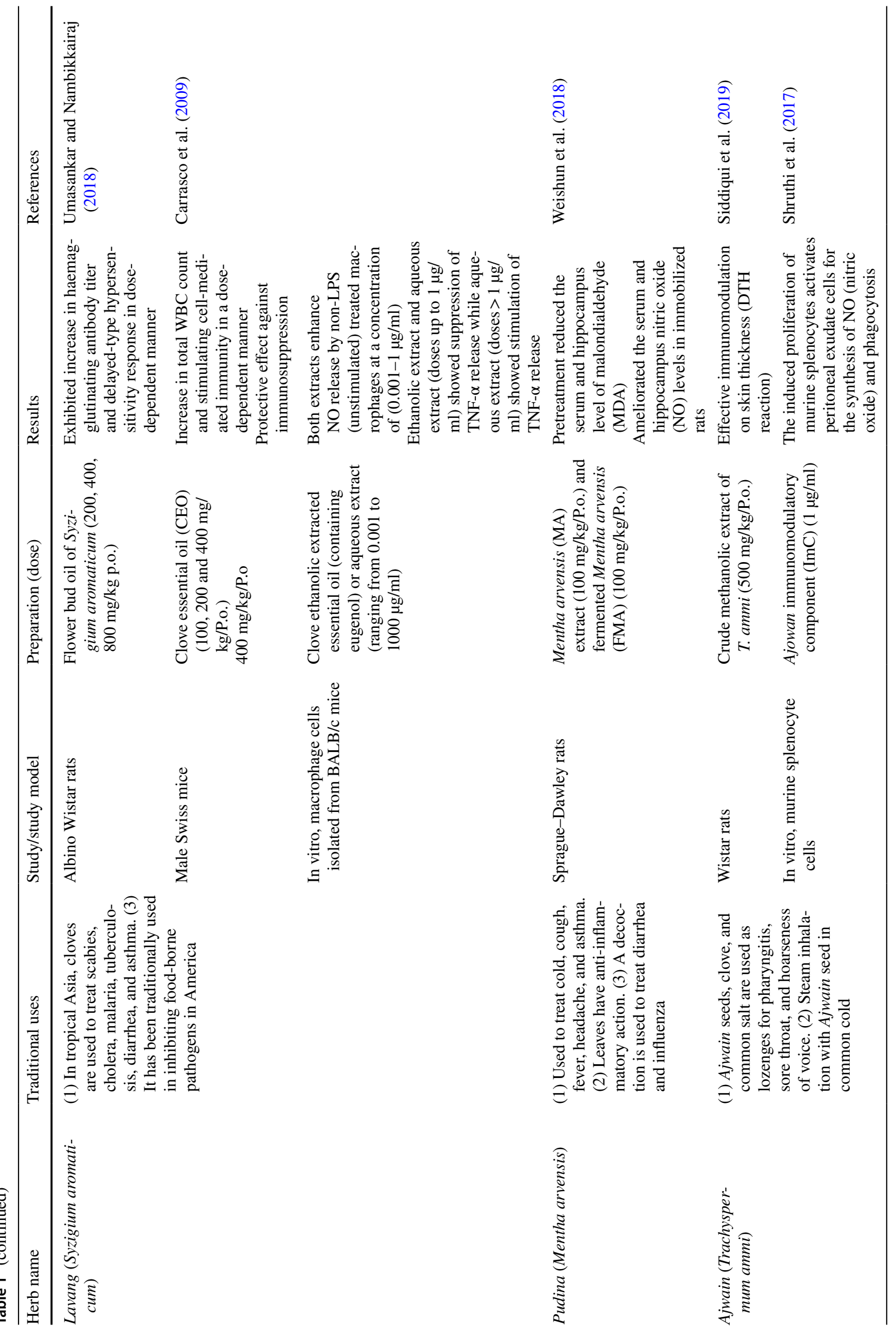


(a)

\section{Haridra (Curcuma longa)}

\section{Curcumin,}

Anthocyanin,

Polysaccharides

unkonan A,B,C,D

Munnaka (Raisin)

$\uparrow \mathrm{Ab}$ production, THI cytokines, stimulates proliferation of $\mathrm{B}$ cells, Antioxidative Reduce viremia period

Oleanolic acid, Oleanolic aldehyde,

Linoleic acid, Flavonol glycosides

Enhanced the secretion of Th1 cytokines, NK cells activity, production of $\operatorname{IgG} 2 \mathrm{a}$, Induced

lymphoproliferative and DTH responses, NO production, macrophages $\uparrow$

\section{Rasona (Allium sativum)}

Lectins, Agglutinins,

Allicin, SAC

$\downarrow$ Pro-inflammatory cytokines CCL3, IL-1 $\beta$, and TNF- $\alpha$ Inhibited viral replication

\section{Maricha (Piper nigrum)}

Piperine Triggering the IL-1 $\beta$, IL- 6 and IFN- $\gamma$ cytokines expression, phagocytosis, Increased T cell proliferation and NK cell activity, bactericidal activity

Shunthi (Zingiber officinale)

Gingerol,

Shogaols,

Zingerone,

Gingerdiones

Affect membrane integrity of pathogen, biofilm formation $\downarrow$, showed efflux activity,

Increased plaque-forming cell count and antibody, Recovers the humoral immune response
Jiraka (Cuminum cyminum)

$\uparrow$ total WBCs count, splenocyte Coumarine,

proliferation and impairing Thymoquinone,

bacterial cell membrane

Anthraquinone

$\uparrow \mathrm{T}$ cells (CD4 and CD8) count

and $\mathrm{Thl}$ predominant immune response

Tulsi (Ocimum sanctum)

Elevated level of TNF- $\alpha$, IFN- $\gamma$
$\begin{aligned} & \text { and IL-2 cytokines, GABAergic } \\ & \text { pathway, Lymphoproliferation }\end{aligned}$

ImmunO pathway, Lymphoproliferation

Inhibited virus replication

Polyphenol

modulati

Anxiolytic antidepressant effect

\section{Stimulated}

lymphoproliferation, induced

$T$ cell differentiation

Inhibition of virus-induced

Twak (Cinnamomum)

on

\&

Anti

cytopathogenicity

Cinnamaldehyde

derivatives BCA \&

HCA

microbial

Lavang (Syzigium aromaticum)

Action

Inhibiting viral DNA polymerase, Eugenin, Eugenol,

showed virucidal activity $\quad$ Flavonoids

Inhibited release of cytokines (IL-1,

TNF- $\alpha$, IL-6 and IL-8)

$\uparrow$ haemagglutinating antibody titre,

WBCs count and DTH response

\section{Chywanprash}

$\uparrow$ secretions of TNF- $\alpha$, MIP- $1^{\alpha}$, IL- $1 \beta$ and

NK cell activity and phagocytic activity $\uparrow$

Modulated IgE and immunity markers $\mathrm{C} 3$

Vitamin C,

Polyphenolic, and $\mathrm{C} 4$ levels

(b)

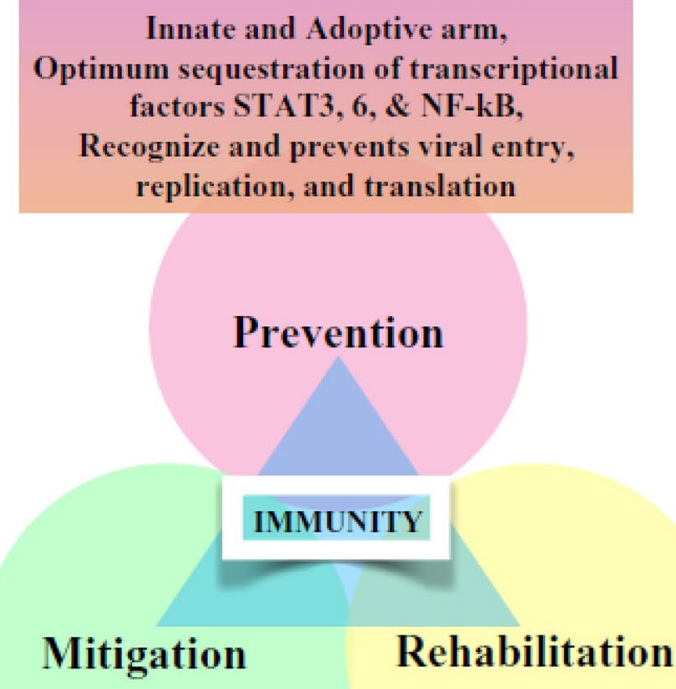

Immunomodulation,

Efficient antigen presentation signaling circuits,

Well maintained positive and negative feedback cycles, Equipoised therapeutic or offensive immune strategies
Regeneration, replacement, and regrowth of key role immune players like progenitor cells, transcriptional factors, cytokines, and growth factors, Healthy sequestration of apoand co-enzyme genes 
4Fig. 1 a Immunomodulatory and anti-microbial action of herbs advised by AYUSH, India. Advised herbs, their major phytoconstituents, and possible mechanism of actions leading to immunomodulation, anti-microbial, and anti-oxidative actions. Ab-antibodies, Th1-T helper type 1, Nk cells-natural killer cells, IgG2a-immunoglobulin G 2a, DTH-delayed-type hypersensitivity, NO-nitric oxide, CCL3 - Chemokines (C-C motif) ligand 3, IL-1 $\beta$ - interleukin $1 \beta$, IL-6-interleukin 6 , IFN- $\gamma$-interferon-gamma, WBCswhite blood cells, CD4-Cluster of differentiation 4, TNF $\alpha$ - tumour necrotizing factor $\alpha$, MIP $1 \alpha$-macrophage inflammatory protein $\alpha$, and IgE-Immunoglobulin E. b Preventive, mitigation, and rehabilitation role of immunity to the viral threat

the immune cells as well as microbes that could also provide useful insights to the development of potentially useful new pharmacological agents (Fig. 2). Rasona is an Ayurvedic Sanskrit name for Garlic (Allium sativum L.; Family: Amaryllidaceae) that enhances the functioning of the immune system by stimulating macrophages, lymphocytes, natural killer (NK) cells, dendritic cells, and eosinophils, through mechanisms like modulation of cytokine secretion, immunoglobulin production, phagocytosis, and macrophage activation (Arreola et al. 2015). Garlic compounds, like sulfur-containing components, showed a modulatory effect on $\mathrm{T}$ cell proliferation. Cuminum cyminum (Jiraka) possesses immune stimulatory property possibly through thymoquinone (TQ). The black cumin seeds are proved effective for the treatment of diseases such as asthma, bronchitis, rheumatism, and other inflammatory diseases (Srinivasan 2018). Cuminum cyminum stimulated the $\mathrm{T}$ cells (CD4 and CD8) and Th1 cytokines expression in normal and immune-suppressed swiss albino mice (Chauhan et al. 2010). Antibacterial activities of cumin, cardamom, and dill weed essential oils were evaluated against Campylobacter jejuni and Campylobacter coli showed inhibition of Campylobacter species by impairing the bacterial cell membrane (Ingok and Guler 2017). Coriandrum sativum (Dhaanyaka) leaves contain vitamins, minerals (phosphorous, calcium and iron) and it is a major source of lipids, petroselinic acid, and monounsaturated fatty acid (Mandal and Mandal 2015). Plantaricin C. sativum, an antimicrobial peptide isolated from coriander leaf extract and coriander essential oil exhibited antimicrobial activities against different strains of bacteria's in two different studies (Masoud et al. 2014). Immunomodulatory and antimicrobial in vivo/in vitro and clinical studies of all recommended spices/herbs are summarised in Table 1.

An open level, comparative clinical study administering add-on Ayurvedic treatment with Standard of Care (SoC) in COVID-19 positive cases expressed fast recovery and early discharge in patients received Dasamooladuthrayam Kashaya and Guduchi Kwatham with SoC than SOC alone (Khedkar et al. 2020). Results of undergoing Ayurvedic herbs trials on recovery rate, virus loads, and immunological markers of COVID-19 are awaited (Rangnekar et al. 2020).

\section{Ayurvedic procedures}

Ayurveda advocates Nasya (instillation of medicine through nostrils) for the prevention and mitigation of diseases. Absorption of drugs from the nasal cavity occurs through two routes i.e. paracellular (slow, passive, and aqueous route of transport) and transcellular (rate dependent, active and lipophilic route of transport) (Bale et al. 2015). Advisory recommended applying sesame oil/ coconut oil or ghee in both the nostrils twice daily (morning and evening) called Pratimarsha nasya. This therapy cleanses, purifies, and strengthens the nasal passages, likely to act as a "physiological mask" and may prevent virus fatty acid layer adherence to moist mucosa of the nasal or oral cavity (Tillu et al. 2020). The sesame seed oil contains important active compounds such as major lignans, phytosterols, and vitamin E especially $\gamma$-tocopherol which has immunomodulatory and antimicrobial activity (Nonaka et al. 1997). Advisory also recommended oil pulling therapy (Kavala or Gandusha: a traditional procedure in which the practitioner rinses or swishes oil in his mouth). It is supposed to cure oral and systemic diseases. It is a powerful detoxifying ayurvedic technique that is preventive as well as curative (Hooda et al. 2017). Cocos nucifera Linn. (Coconut) oil is an easily available edible oil that contains predominantly medium-chain fatty acids (lauric acid) that have proven anti-inflammatory and antimicrobial effects (Peedikayil et al. 2015). In an observermasked, randomized, volunteer-based cross-over clinical trial, coconut oil pulling seems to have similar plaque inhibition activity as $2 \%$ chlorhexidine gluconate (CHX) with less tooth staining than CHX (Sezgin et al. 2019).

Non-pharmacological procedures like Yogasan, Pranay$a m a$, and Dhyaan (meditation) have been advised routinely at least $30 \mathrm{~min} /$ day in AYUSH guidelines to reduce stress, anxiety, enhance immunity, etc. Every day, an instructor displays the Asanas technique on the website of the AYUSH ministry in the form of a video for the people to follow. Pranayama (breath regulation) an essential component of Yoga, positively influences the physiology of the human body. Stress hurts the immune system and prolonged exposure is linked to physical and mental health problems (Segerstrom and Miller 2004). Yoga modulates levels of immunoglobulins and viral recognition cells (NK cells) and moderates C-reactive protein and other inflammatory cytokines in the blood (Shete et al. 2017). Yoga practice optimizes sympathetic responses of the body to stressful stimuli and restores autonomic regulatory reflex mechanisms by inhibition of the posterior or sympathetic area of the hypothalamus. It inhibits median forebrain centers and other areas liable for 


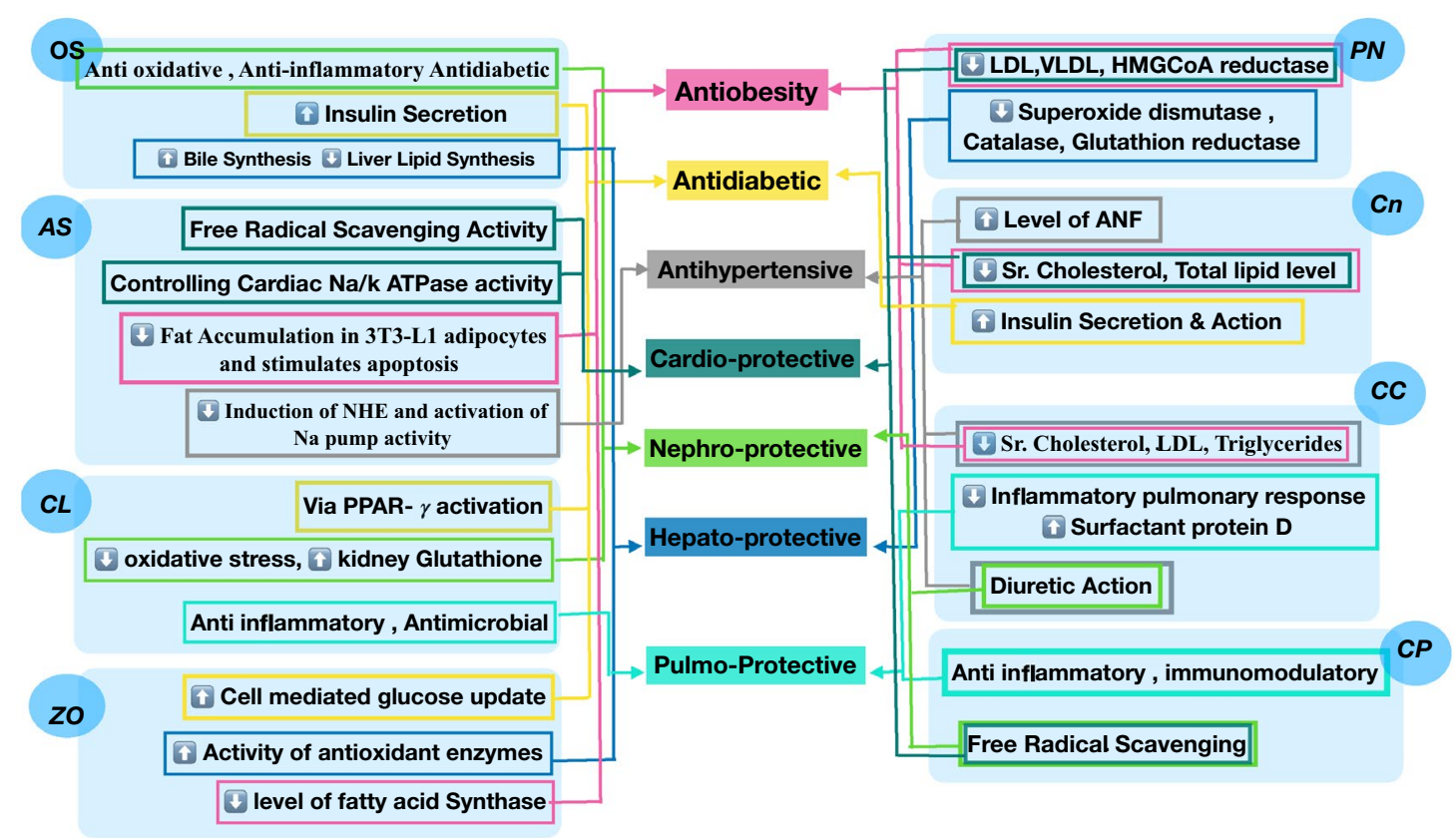

Fig. 2 Role of advised herbs in COVID-19 associated co-morbidities. Protective role of advised herbs and their mechanistic properties against co-morbidities associated with COVID 19. Mechanistic properties of herbs are reflected through the same colour lines, borders, and complete filled borders. Dual activity is shown in double colour boxes. OS: Ocimum sanctum, AS: Allium sativum, CL: Curcuma

fear, aggressiveness, and rage, coupled with stimulation of the rewarding pleasure centers resulting in a state of bliss and pleasure (Woodyard 2011) and increase multiple antidepressant neurotransmitters and hormones such as GABA, serotonin, dopamine (Stephens 2017) and decrease the levels of monoamine oxidase that breaks down neurotransmitters and cortisol (Kamble 2019). Yoga practices may inhibit the activity of the paraventricular nuclei of the hypothalamus, resulting in reduced ACTH production and decreased synthesis of cortisol, and aldosterone lead to down-regulate stress responses (Arora and Bhattacharjee 2008). The process and interrelation between stress, immunity, morbidity susceptibility, co-morbidities, and Yogic practices are summarised in Fig. 3.

Dhyaan (meditation) increases the expression of brainderived neurotrophic factor (BDNF) and the thickness of the left hippocampus that essentially plays a role in the resiliency to chronic stress and depressive states (Taliaz et al. 2011). Chronic stress flare-up the aging process in association with decreased telomerase activity and telomere shortening. A big positive association between comprehensive lifestyle changes (including Yoga, meditation, breathing, healthy whole-food, and plant-based diet), and increased telomerase activity in human peripheral blood mononuclear cells was found (Ornish et al. 2008). An open-label longa, ZO: Zingiber officinalis: PN: Piper nigrum, Cn: Cinnamomum, CC: Cuminum cyminum, CP: Chyavanprash, Na/K-ATPase: Sodium potassium-ATPase, Ca: Calcium, PPAR- $\gamma$ : Peroxisome proliferator-activated receptor-gamma, LDL: Low-density lipoproteins, VLDL: Very low-density lipoprotein, HMG-CoA: $\beta$-Hydroxy $\beta$-methylglutaryl-CoA, and ANF: Atrial natriuretic factor

cohort study performed on 54 depression patients (high serum cortisol level), subjects in the Yoga groups (Yoga alone and Yoga with drug therapy) had significant drops in their cortisol levels in comparison to the drug-only group $(p<0.008)$. In Yoga only group, there was a high correlation between decreased cortisol levels and lower scores on the HDRS (Hamilton Depression Rating Scale) indicating a positive antidepressant effect as well $(p<0.001)$ (Thirthalli et al. 2013). A randomized controlled clinical test performed among high stressed college students assessed the consequences of sun salutations or Suryanamaskar (a series of 12 physical postures in conjunction with breathing). After 14 days of practice, the experimental group scored higher on mental calmness, joy, strength, physical relaxation and feeling at ease, and scored lower on physical fatigue, somatic stress, and negative emotional feelings in comparison with the control group (Godse et al. 2015).

Pranayama or breath regulation includes modulation of the pace of breathing, viz. slowing down or pacing the breath, manipulation of nostrils, chanting of humming sounds, retention of breath, etc. Pranayama techniques are also beneficial for treating a range of stress-related disorders. Anuloma-Viloma-Pranayama (AVP), i.e., alternate nasal breathing exercise creates negative pressure within the cavity hence improves oxygenation (better surface 


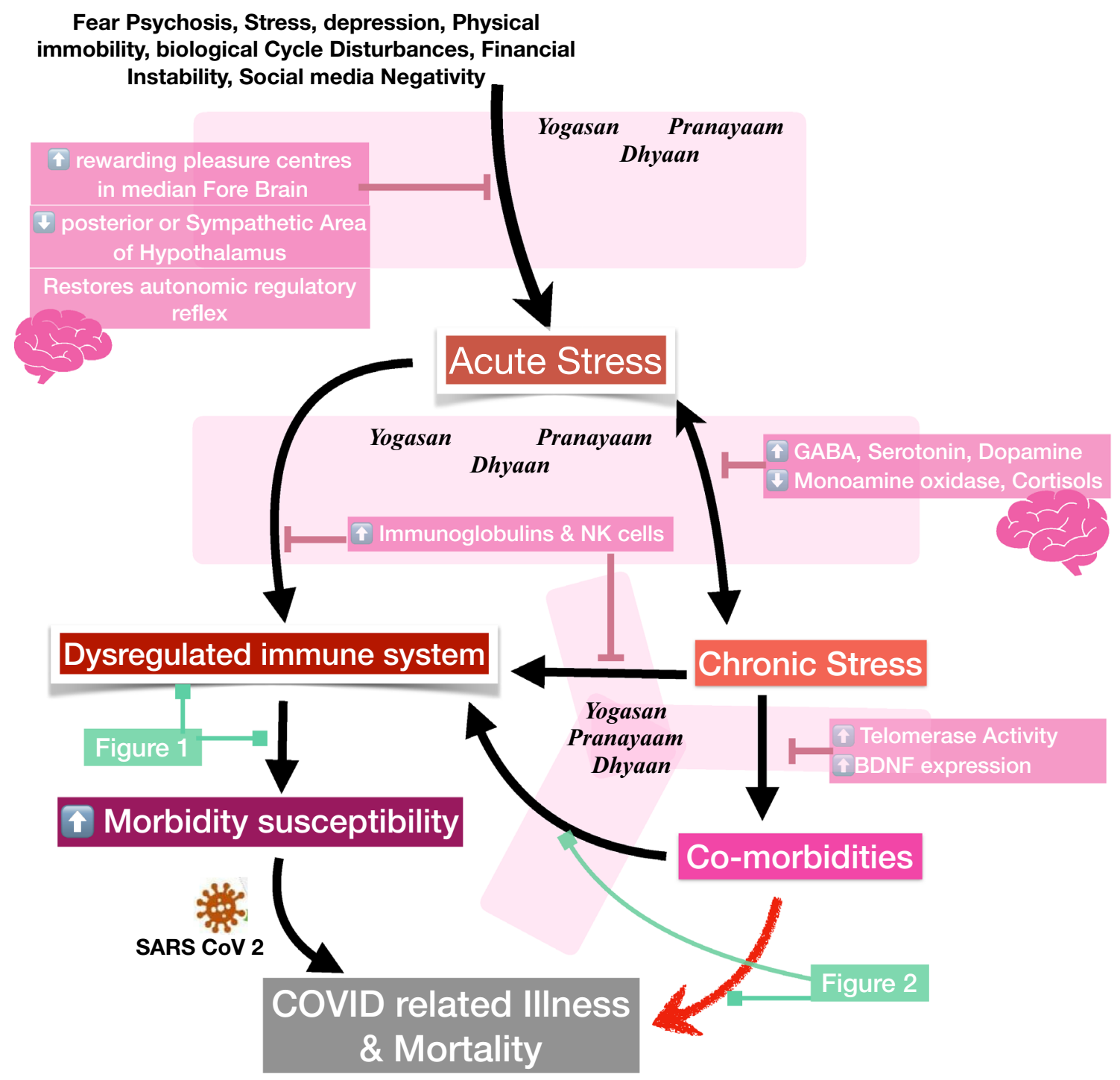

Fig. 3 Psychoneuroimmunology correlation and protective effect of Yoga in modulation of acute stress, chronic stress, equipoise immune system, and COVID-19 associated co-morbidities. Multiple stimuli exaggerate acute stress leading to chronic stress and vice versa. Stress causing immune alteration eventually morbidity susceptibility and

availability) and ventilation of the paranasal sinuses and nasal respiratory epithelium (Bhardwaj et al. 2013). A set of 3 Pranayama breathing exercises was found to increase lung functions (PEF and FEV1) after only 6 weeks of three 10-min each practice sessions per week in healthy volunteers (Kupershmidt and Barnable 2019). The Intervention arm, COPD assessment test scores after 3 months of Pranayama practice, showed improvement in the subjective experience of health, disease severity, and functional status for COPD patients, with airflow limitation not fully reversible but usually progressive (Gupta et al. 2014). In an observational, prospective, quasi-experimental study done prone to COVID-19 illness if contracted to SARS-CoV-2 virus. Yoga modulates, weakens, reduces the stress intensity through various mechanisms as shown in the figure. GABA-Gamma-aminobutyric acid, BDNF-Brain-derived neurotrophic factor, NK cells-Natural killer cells

on elderly COVID-19 patients (65 yrs or above) recruited from Hainan General Hospital and Huanggang central hospital, six-week respiratory rehabilitation improved respiratory function (FEV1, FVC, FEV1/FVC\%, and DLCO\%), Quality of life, anxiety and depression scores (Liu et al. 2020).

Yoga is effective in improving dyspnea, inflammatory markers, respiratory functions (Tidal volume, vital capacity, minute ventilation, respiratory rate, forced expiratory volume (FEV1) and forced vital capacity (FVC)), cardiac functions (blood pressure, heart rate, pulse duration, upstroke time, ejection duration index, diastolic time) and Quality of life as a standard cardiopulmonary rehabilitation 
(Guleria et al. 2015). The Yoga practice induces beneficial changes in cardiovascular function in a parallel arm, openlabel, single-blind, randomized controlled study conducted on elderly people (age above $60 \mathrm{yrs}$ ) with stage-I hypertension. The basal oxygen consumption is reported to be up to $15 \%$ less in regular yoga practitioners as compared to non-practitioner (Patil 2016). 3 months of regular yoga breathing practice is reported with decreasing oxygen consumption by $36 \%$ (Tyagi 2013). The effects of yoga on pulmonary volumes and respiratory muscle strength verified in 36 elderly women showed a decrease in heart rate (HR) and respiratory rate $(R R)$ in the yoga group $(76-39 \pm 8-03$ vs. $74-61 \pm 10.26 \mathrm{bpm}$ and $18.61 \pm 3.15$ vs. $16.72 \pm 3.12$ res/ min. respectively) with improved tidal volume, minute ventilation, vital capacity, maximal inspiratory pressure, and maximal expiratory pressure (Bezerra et al. 2014).

Ayurveda and Yoga can mitigate the health and social impact of COVID-19 illness. Ayurvedic pathophysiology of COVID-19 is understood (Pandkar and Sachdeva 2020) and multiple clinical results also support the standalone or adjuvant benefits of Ayurvedic medication. In a randomized placebo-controlled pilot clinical trial, Ayurvedic oil, herbs, and herbo-mineral preparations were administered orally and intranasal. Patients were evaluated for clinical severity, viral loads, and inflammatory markers. The study concluded that Ayurveda intervention can expedite viral dissemination, equipoised inflammatory markers, and no ADR link to intervention (Devpura et al. 2021).

\section{Discussion}

Ayurveda postulates a foremost treatment of any disease is Nidan Parivarjan (eradication of causative), followed by treatment of disease (Sanshaman and Sanshodhan) and followed by do's and don'ts related to illness, food, daily regimes, and seasonal regime (Prasad 2002). The two main factors that contribute to infection are exposure and poor immune status. In Ayurveda, the concept of Vyadhikshamatwa has many broad implications than the term "Immunity" used in modern medicine (Masram et al. 2014). The word Vyadhi-kshamatwa" is made up of two words; Vyadhi (disease) and Kshamatwa (suppress or overcome). It is defined as Vyadhibala-Virodhitwa (antagonistic to the strength and virulence of the disease) and Vyadhyutpada Pratibandhakatwa (capacity to inhibit and bind the causes and factors of the disease). Acharya Sushrutha has mentioned that the Ojus is the finest essence of all of our body tissue and this Ojus is said to be Bala (strength of body) (Trikam and Sharma 2002). There is a close relation between Bala and Vyadhi-kshamatwa, when there is an increase in Bala, there is an increase in Vyadhi-kshamatwa and viceversa (Masram et al. 2014; Byadgi 2011). The continuous accumulation of Aama (a pro-inflammatory product of impaired metabolic disorder) in the body blocks the channels of energy and nutrition, which in turn decreases the level of Bala and finally compromised the Vyadhi-kshamatwa of the body (Byadgi 2011). Stress, pathogens, viruses, various chemicals, wrong food habits, and so on are responsible for the accumulation of Aama in the body leading to increased susceptibility to disease. Drinking hot water is a basic measure to digest Aama (Tillu et al. 2020).

Ayurveda, the science of life, is based on preventive care employing Dinacharya (daily regime) and Ritucharya (seasonal regime) to maintain the balance of Doshas (maintain homeostasis of body and mind). Self-care advisory incorporates aspects of promotion and strengthening of Vyadhikshamtwa and Bala. Through centuries, India had managed/ combat pandemics (Janpadodhwans) through the wisdom of Ayurveda and natural resources (Priya and Sujatha 2020). Ayurveda literature promotes Rasayana therapy along with physical and social distancing from infected persons for prevention and overcomes epidemic situations (Rastogi et al. 2020). Traditional Chinese Medicine has applied its diagnostic concept in identifying the current syndrome (COVID-19) and treated accordingly. Ayurveda should also work on the same line of diagnosing through its diagnostic concepts following treatment according to RogiBala and Vyadhi-kshamatva.

\section{Immunity, immunomodulation, and SARS-CoV-2}

The immune components have continuing inside-out and outside-in communication at molecular, cellular, histological, and systems levels to maintain the body homeostasis. This routine house-keeping vs. concerted strategized response to an incumbent situation (altered normal) dialogue is what keeps a human body healthy and able to overcome challenging situations. Host immunity against viral is largely innate (first and second lines of defense) and also auto-regulated. Acquired or memory-directed immunity usually does not need to kick in during a virus lytic cycle. When a virus changes from lytic to lysogenic cycle (i.e. assumes a more long-term association with the body), it leads to a powerful and unregulated innate immune response leading to devastating results.

For SARS-CoV-2, an unregulated cytokine storm seems to be an important watershed reaction leading to fatality. Just like in allergic response, some persons may and some may not respond to an allergen in the environment because of 'primed' dendritic and other antigen presentation cells that process and activate the allergenic circuit. Similarly, $80 \%$ of individual do not show symptoms of SARS-CoV-2 although they harbour the virus in their body and may act as carriers, while others (15\%) show moderate symptoms, and only $5 \%$ show the severe form of disease requiring ventilation and 
these individuals (with or without co-morbidity) tend to succumb to the COVID-19. SARS-COV-2 manifestation is akin to other influenza viruses such as HKU-1, NL6, and OC43 which cause mild forms of pneumonia. SARS-COV-2 on the other hand is unusual in the sense, it quickly unlocks its replicon and usurps the host's transcriptome using its enzymes 3CLpro, RDRP, and other NSPs. ACE-2 is expressed on all blood vessel cells, monocytes, dendritic cells, and macrophages in tissue spaces that interact with spike protein of virus for internalization inside the host cell. It resulted in inflammation (innate immune response), release low levels of IFN- $\gamma$, and then the mononuclear macrophages start secreting high levels of IL- 6 , TNF- $\alpha$, IL- $1 b$, etc. Soon potent inflammation-inducing cytokines secreted in large quantity relentlessly and lost regulatory mechanism to stop it. A positive feedback loop seems to be the hyper-response to the viral proteins that cannot be controlled. Under these circumstances, an efficient immune system needs to have the right proportion of all cells. The signal reception nodes of all the immune circuits must be in good functioning so that once they can respond, certain stimuli be intercepted, and once mounted it must not go on for a very long-time unabated unchecked. The other important thing is the rejuvenation (regeneration, replacement, and repair) of damaged and used-up components of the immune system. The preventive, mitigation, and rehabilitation role of immunity to viral threat is shown in Fig. 1b. AYUSH advisory's phytochemicals and Yoga may induce the Th1/Th17 response for macrophage activation and elimination of SARS-COV-2 pathogens. They could support regenerating the required repertoire for the development of certain cell types to be efficiently and correctly occurring during infection (Rastogi et al. 2020; Kar et al. 2015; Das et al. 2016).

From data generated by scientific experiments, curcumin, piperine and various phenolic compounds (Paul et al. 2018; Das et al. 2015) have already shown immuneboosting not in the sense of activation but rather to maintain, regenerate, and ensure the efficiency of key immune components and their connecting circuitry in the rest of the systems (none of them exist in isolation). Nutritional ligands of PPAR-y like Curcuma Longa and others are under scrutiny as a potential candidate for cytokine storm modulation in COVID-19 (Ciavarella et al. 2020). Pro-inflammatory innate responses are not misfired and in case there is an over-stimulation, they act as inflammation regulatory elements to bring the inflammatory cascade down. Almost 10 herbal drugs are screened for their immunomodulation effects (Fig. 1a). Recently, a clinical trial of some Ayurveda drugs as add-on therapy and standard care for COVID-19 has been launched. The lead herbs are G. glabra Linn., W. somnifera Linn., T. cardifolia, P. longum and poly-herbal medicine. Chyawanprash, a component of advisory contains these four herbs; hence Chyawanprash could also be extended to COVID-19 care if trials post positive results.

Suffice it to say, the functional food, prophylactic-therapeutic phytochemicals, Ayurvedic procedures, frequency and synchronicity of important diurnal events for maximum efficacy by the chrono-biological system of the body's cells and their bioavailability to affected tissue, may ensure transcriptomic and/or metabolomic sequestration of the required components (cellular and non-cellular) and their proper communication in the body with time to ensure optimum balance to keep the immunity (Vyadhukshamata), samprapti-vigathan (break of disease cascade), etc. in synchrony. Self-care advisory can streamline and maintain immunological, social, diurnal, and mental balance. Ayurveda fortified by Yoga, Dhyana, and Pranayaam ensure perfect rhythm and wellstocked repertoire of an already efficient and well-endowed immune system to combat the current pandemic situation.

\section{Apprehensions about AYUSH advisory}

\section{Evidence, drug interaction, efficacy, and safety}

An international advisory released by WHO, welcoming innovation like drug repurposing and traditional medicine in search of a potential treatment for COVID-19. This advisory also expressed concern for safety, efficacy and adverse side effects of certain remedies like Artemisia апnиа Linn. (family-Asteraceae) (Sweet wormwood, Chinese nameqinghao and famous as COVID-ORGANICS) touted as possible treatment backed by several African nations. "Natural and safe" a perception linked with herbal products is not always true. Many herbs have reported toxicity and adverse drug reactions. Clinical, in vivo and in vitro safety and toxicity profile studies for advised drugs are searched, analyzed, and discussed in Table 2, Although most of these herbs are food or dietary supplements so pharmacological vigilance is not compulsory. Sufficient works had been carried out on Chyawanprash, no evident information on toxicity has been available to date. It is considered safe in prescribed dosage (10 g/P.o. in the morning as recommended by AYUSH advisory). Agbaje et al. (2009), concluded that indiscriminate and long-term use of Syzigium aromaticum could be hazardous to body health so must be ingested with caution. (already in below table). No study has shown any significant toxicity except few in doses much higher than therapeutic limits. We searched Uppsala Monitoring Centre (UMC) (www.vigia ccess.org) and Ayushsuraksha (AYUSH pharmacovigilance reporting site) (www.ayusuraksha.com) for adverse drug reactions (ADRs) associated with these herbs. UMC on date 23th May 2020, ADRs reported for P. nigrum, O. sanctum, C. cyminum, Cinnamomum, and $M$. arvensis are 2, 1, 6, 68, and 26 respectively. ADRs for A. sativum, Z. officinalis and 


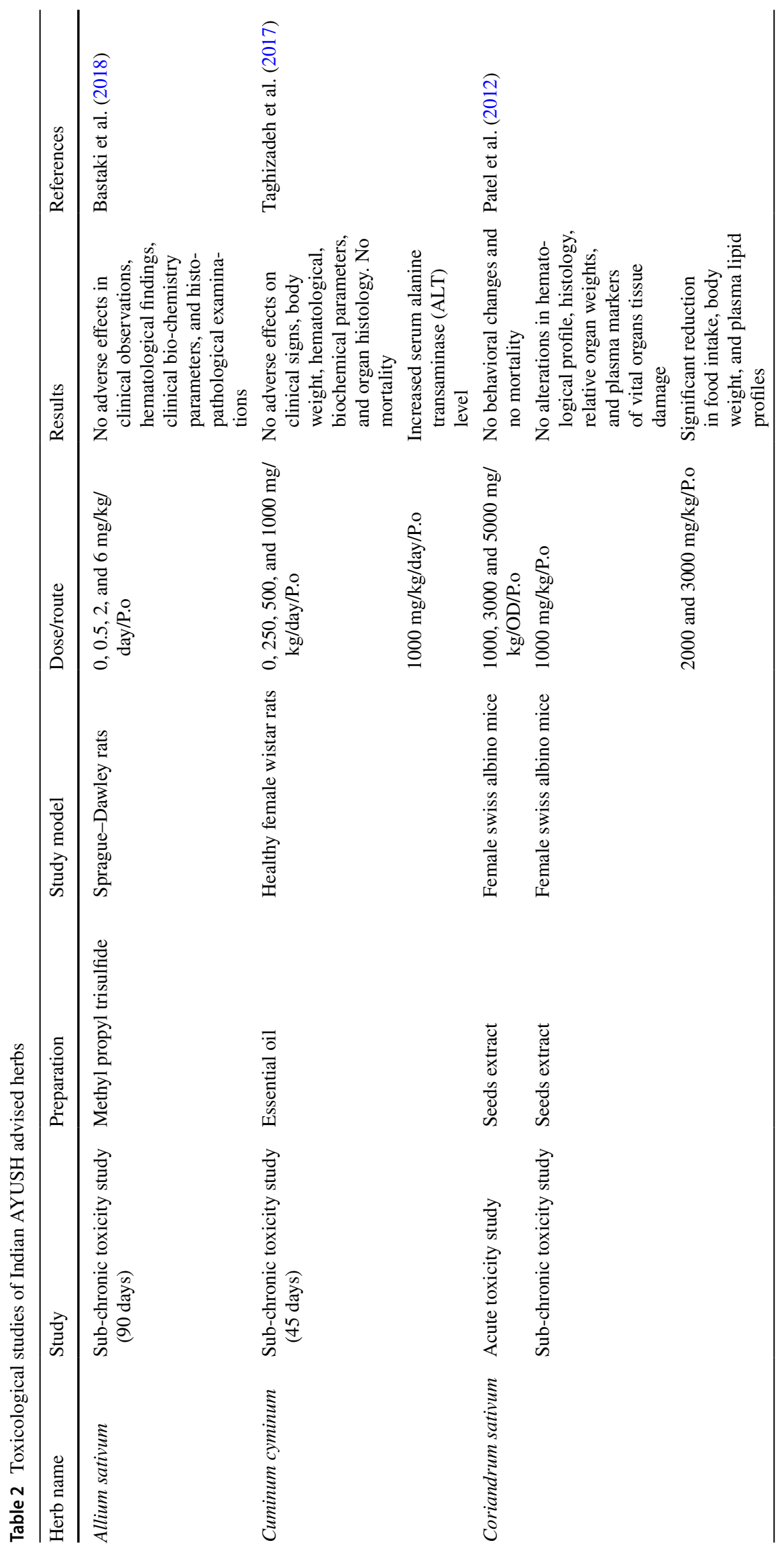




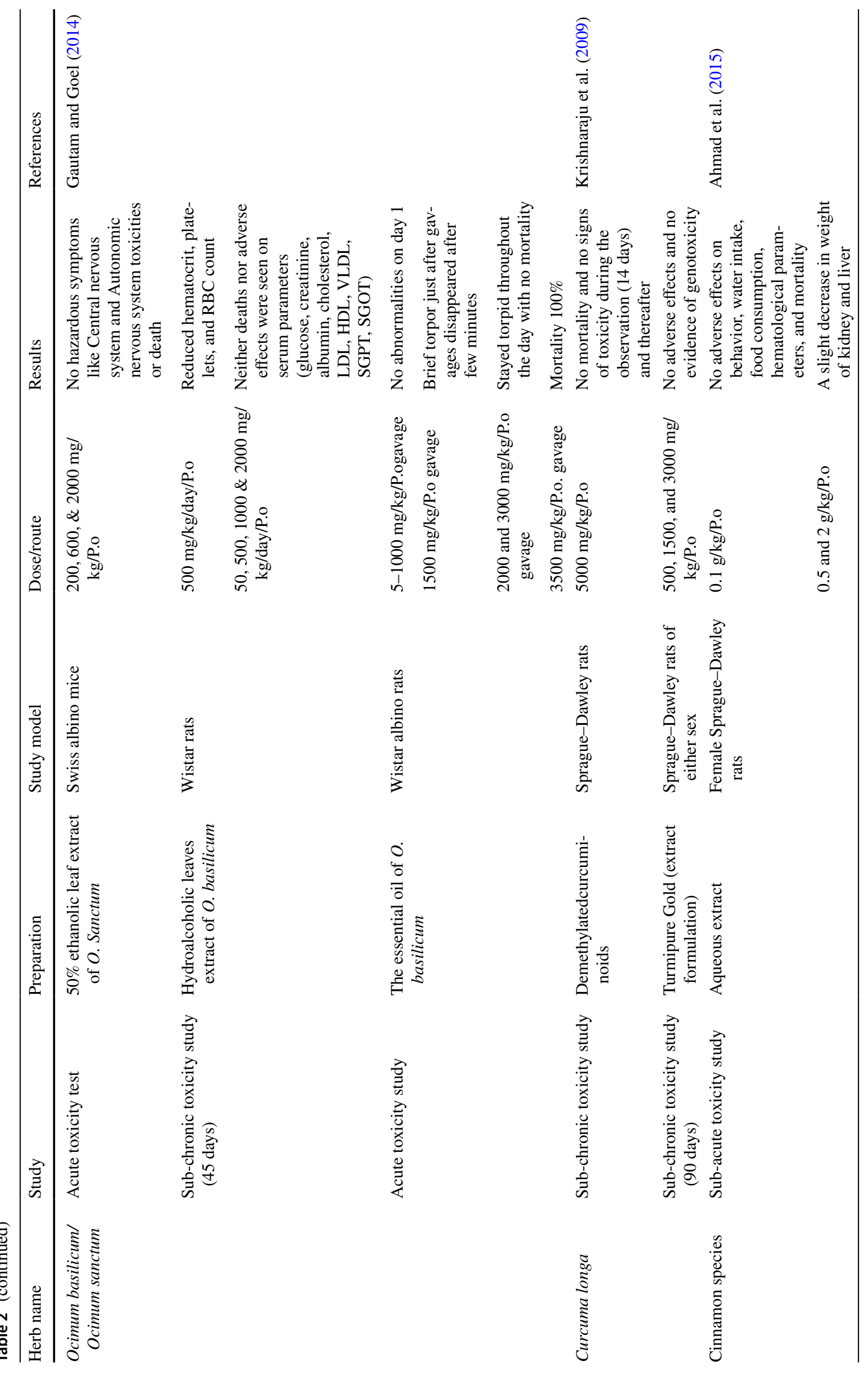




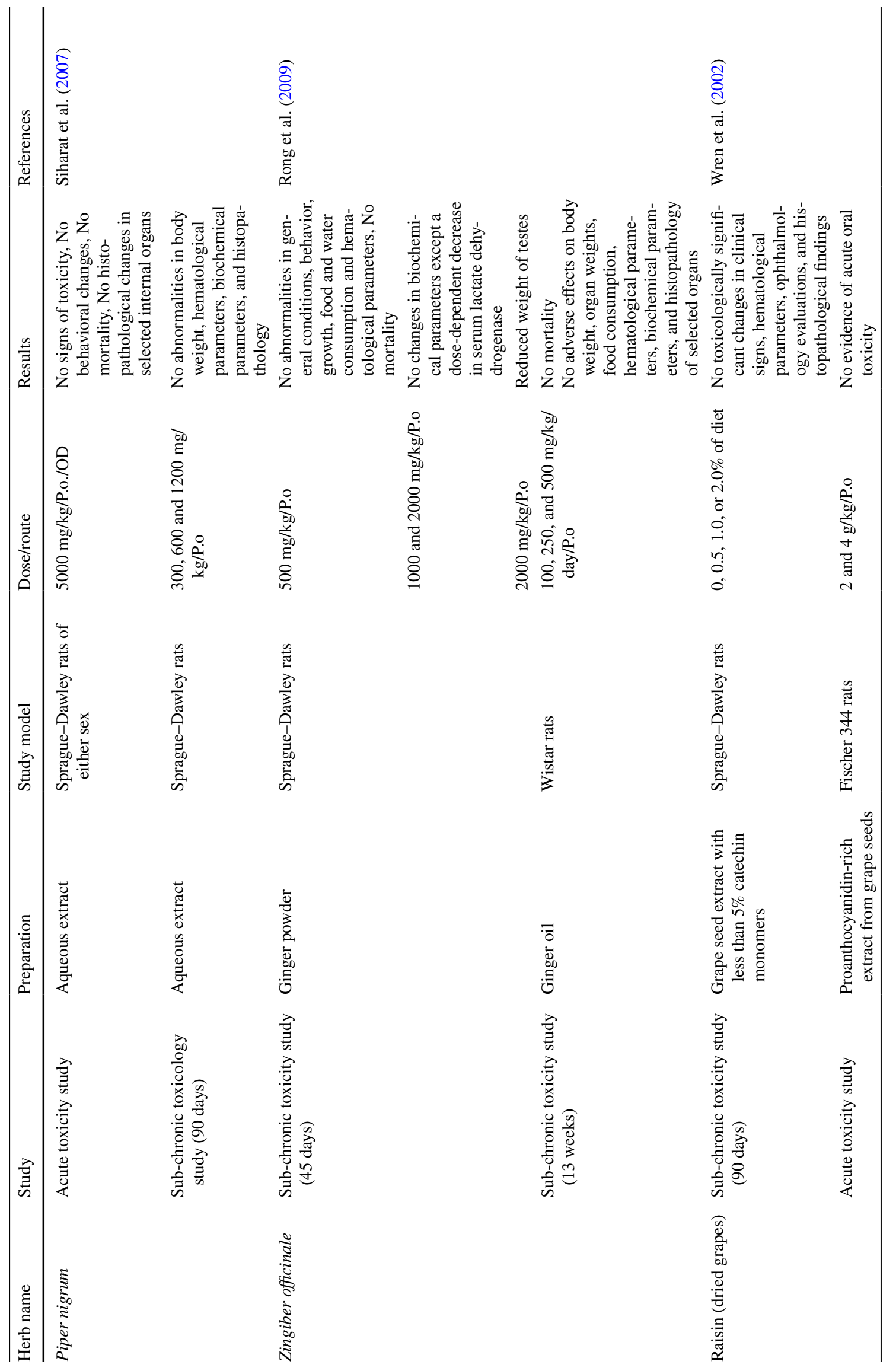




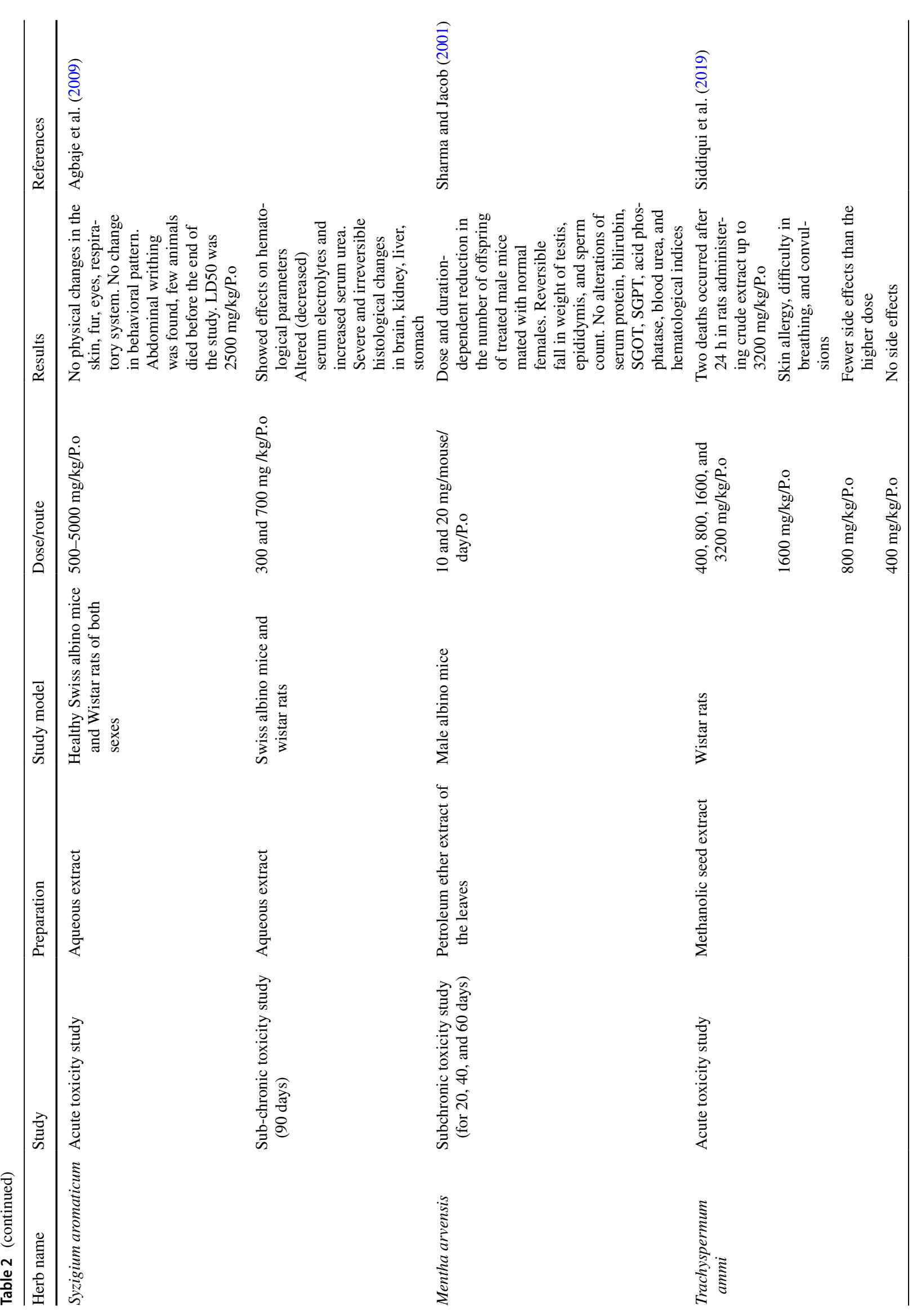


C. longa are 216, 399, and 226 respectively while Chyawanprash, S. aromaticum, and T. ammi has no reported ADR to date. These numbers are negligible in comparison to ADRs reported of another prophylactic drug like hydroxychloroquine $(23,994)$ and paracetamol $(149,820)$. The above data support the safety of advisory for longer human uses. Although limited access and information are available may be due to under-reporting or less known reporting procedure. Ayursuraksha, an Indian ASU pharmacovigilance reporting site, has no available data for public access to get an idea of ADRs reported to date for a particular herb, active ingredient, and their combination.

Guidelines issued are self-care, so no unsubstantial claims and no Ayurveda professional practice is promoted. Ministry of AYUSH issued a notification prohibiting the mongering of unsubstantiated and unauthenticated claims of curing COVID-19 through AYUSH medicines. It stated that all Indian states and Union Territories are directed to stop or prevent publicity and advertisement of AYUSH related claims for COVID-19 treatment in television, print media, and electronic media. This step has fairly regulated the claims made through e-platforms and print media (Anonymous 2020)

\section{International relevance}

More than 30 traditional medicine guidelines (for treatment alone 26 from china, 2 from South Korea) for prevention, prophylaxis, and treatment of COVID-19 have been issued till 12 May 2020. Many nations have adopted the translated version like Japan has adopted the translated version of Traditional Chinese Medicine (Lin et al. 2020). Indian AYUSH self-care guideline is translated in 5 united nation (UN) languages and 3 other international languages; hence it was eminent to see such advisory in light of current science and public health prospect.

\section{Stress, anxiety, depression, fear, psychosis, psychoneuroimmunological correlations, and Yoga}

The concept of the psychosomatic phenomenon has its roots in one of the traditional/classical Yoga texts (The Yoga Vashista, codified nearly 5000 years ago) termed as Adhija-Vyadhi. Uncontrolled, long-standing stress at Manomaya Kosha (Mental body) may lead to disturbances in the Prana (vital energy-similar to Qi), and manifest the disturbances in the Annamaya Kosa (Physical body) may result in several psychosomatic diseases. Stress, anxiety, depression, fear psychosis, sleep disturbances, loneliness (lockdown effect) are associated with the ongoing COVID-19 pandemic. Psychoneuroimmunology (PNI) studies showed correlation between the state of mind and the state of physical health (Singh et al.
2015). Eustress helps to cope with the demanding situation at the physical, mental or emotional level, but uncontrolled long-standing stress/chronic stress can have an immunosuppressive effect, a risk factor for COVID-19. Stress may dysregulate different immune parameters (e.g. inflammatory pathways) and lead to disease. Elevated pro-inflammatory cytokine production may generate sustained upper respiratory infection symptoms. Limited studies are carried out to evaluate the effect of Yoga on the immune system and it may decrease IL-1 $\beta$, IL- 6 , and TNF- $\alpha$ in inflammatory stages and reflects immunomodulation (Falkenberg et al. 2018). Increasing psychological resources (mindfulness, body consciousness, self-transcendence, spiritual peace, and social connectedness) may bring about salutary effects on emotional wellbeing. PNI correlation and protective effect of Yoga in modulation of acute stress, chronic stress, comorbidity, and immune system are explained in Fig. 3.

Endocrine, nervous and immune systems are interconnected, so disruption in one creates an impact on the other. Yoga activates neurohormonal mechanisms by inhibiting the posterior or sympathetic area of the hypothalamus, optimizes sympathetic responses to stressful stimuli, restores autonomic reflexes associated with stress, increases the parasympathetic activity thus reduces stress, anxiety, balances autonomic functions and hormonal secretions (Balasubramaniam et al. 2013). Yoga therapy was also found beneficial in enhancing immunity, sleep, cardio-pulmonary fitness, and telomere length in regular practitioners (Ornish et al. 2008; McCall et al. 2013). The above discussion supports that Yoga, Pranayaam, and Dhyaan can be a better way of managing stress in the current pandemic situation.

\section{Co-morbidities management through drugs and non-pharmacological procedures}

Emerging data suggest an increased association and a heightened mortality in patients of COVID-19 with comorbidities (Singh et al. 2020). Co-morbidities predispose the patients to multi-organ failure during an infection. According to a recently published study on laboratoryconfirmed cases of COVID-19, patients with any comorbidity yielded poorer clinical outcomes than those without. A systematic review and meta-analysis on the prevalence of co-morbidities and their effects in COVID-19 patients revealed that underlying disease, including hypertension, respiratory system disease, and cardiovascular disease, may be risk factors for severe patients compared with non-severe patients (Yang and Zhou 2020). Hence advised drugs were screened for various morbidities associated with COVID19. It was observed that all herbs protect from single or multiple co-morbidities collectively or individually. The role of advised herbs and their mechanism of action against co-morbidities associated with COVID-19 is explained in 
Table 3 The activity and mechanistic properties of the herbs advised by Indian AYUSH for COVID-19

\begin{tabular}{|c|c|c|}
\hline Activity & Herb & Mechanistic property \\
\hline Anti-obesity & $\begin{array}{l}\text { Allium sativum } \\
\text { Zingiber officinalis } \\
\text { Piper nigrum } \\
\text { Cinnamomum } \\
\text { Cuminum cyminum }\end{array}$ & $\begin{array}{l}\text { Decreased fat accumulation in 3T3-L1 adipocytes and stimulates apoptosis } \\
\text { Decreases the level of fatty acid synthase } \\
\text { Reduces LDL, VLDL, HMGCoA reductase } \\
\text { Reduces Serum cholesterol } \\
\text { Reduces Serum cholesterol, LDL, and triglycerides }\end{array}$ \\
\hline Anti-diabetic & $\begin{array}{l}\text { Ocimum sanctum } \\
\text { Curcuma longa } \\
\text { Zingiber officinalis } \\
\text { Cinnamomum }\end{array}$ & $\begin{array}{l}\text { Enhances Insulin secretions } \\
\text { Act through PPAR-activation } \\
\text { Increases cell-mediated glucose uptake } \\
\text { Enhances Insulin secretions and their action }\end{array}$ \\
\hline Antihypertensive & $\begin{array}{l}\text { Allium sativum } \\
\text { Cinnamomum } \\
\text { Cuminum cyminum }\end{array}$ & $\begin{array}{l}\text { Reduces induction of NHE and activation of Na pump activity } \\
\text { Increases level of ANF } \\
\text { Reduces Sr. Cholesterol, LDL, triglycerides, act as a diuretic }\end{array}$ \\
\hline Cardioprotective & $\begin{array}{l}\text { Allium sativum } \\
\text { Piper nigrum } \\
\text { Chywanprash } \\
\text { Cinnamomum }\end{array}$ & $\begin{array}{l}\text { Free radical scavenger, Controls cardiac Na/K ATPase activity } \\
\text { Reduces LDL, VLDL, HMGCoA reductase } \\
\text { Free radical scavenging } \\
\text { Reduces Serum cholesterol, and total lipid level }\end{array}$ \\
\hline Nephroprotective & $\begin{array}{l}\text { Ocimum sanctum } \\
\text { Curcuma longa } \\
\text { Cuminum cyminum } \\
\text { Chywanprash }\end{array}$ & $\begin{array}{l}\text { Anti oxidative and free radical scavenging } \\
\text { Reduces oxidative stress and increases kidney glutathione content } \\
\text { Diuretic action } \\
\text { Free radical scavenging }\end{array}$ \\
\hline Hepato-protective & $\begin{array}{l}\text { Ocimum sanctum } \\
\text { Zingiber officinalis } \\
\text { Piper nigrum }\end{array}$ & $\begin{array}{l}\text { Increase bile synthesis, reduces liver lipid synthesis } \\
\text { Anti-oxidant action } \\
\text { Reduces superoxide dismutase, catalase, glutathione reductase }\end{array}$ \\
\hline Pulmo-protective & $\begin{array}{l}\text { Curcuma longa } \\
\text { Cuminum cyminum } \\
\text { Chywanprash }\end{array}$ & $\begin{array}{l}\text { Anti-inflammatory activity } \\
\text { Manages inflammatory pulmonary response, increase activity of surfactant protein D } \\
\text { Settle pulmonary ailments, immunomodulatory }\end{array}$ \\
\hline
\end{tabular}

Fig. 2 and Table 3. Yoga has also gained popularity as an adjunct therapeutic tool in the management of diabetes, hypertension, obesity, respiratory disorders, autoimmune disorders and other psychosomatic illnesses (Ornish et al. 2008; McCall et al. 2013) hence may equally contribute to co-morbidities management.

\section{Post-COVID-19 rehabilitations}

Evidence from China has shown that recovery will be longer and more complex in COVID-19 patients due to neurological, cardiovascular, and respiratory after effects. The symptoms of COVID-19 disease can range from very mild to severe. Community-acquired pneumonia, ARDS, acute cardiac injury, stress, depression, and acute kidney injury in COVID-19 patients results in decreased activities of daily living and quality of life accompanied by decreased physical and mental function. Many research studies support that $Y$ oga therapy is reported to relieve post-traumatic stress disorder symptoms in war veterans, tsunami survivors, hurricane refugees, and flood survivors (Tyagi 2013). Based on the above discussion, Yoga therapy may prove a beneficial rehabilitative strategy in patients having a history of severe symptoms of COVID-19 in improving dyspnea, inflammatory markers, respiratory functions, cardiac functions, quality of life, and post-traumatic stress disorder as shown in Fig. 4. AYUSH guidelines can help to get back, improve the functioning system of the body as standard rehabilitation therapy (Fig. 5).

There is a need to document the feedbacks of self-care advisory and in this regard, the Indian AYUSH ministry's attempt of "Ayush Sanjeevani" mobile application (covered $>100$ thousand downloads and $>1$ million cumulative feedbacks as of 19 June 2020) and Arogyaduta are appreciable. Advisory has streamlined the AYUSH human resources (> 7 lakh AYUSH practitioners) and associated infrastructure (near 25,000 health facilities) in India.

\section{Conclusion}

From time to time, scientific advisory released by the national government of a country has great significance and is considered as an important medical guideline but 


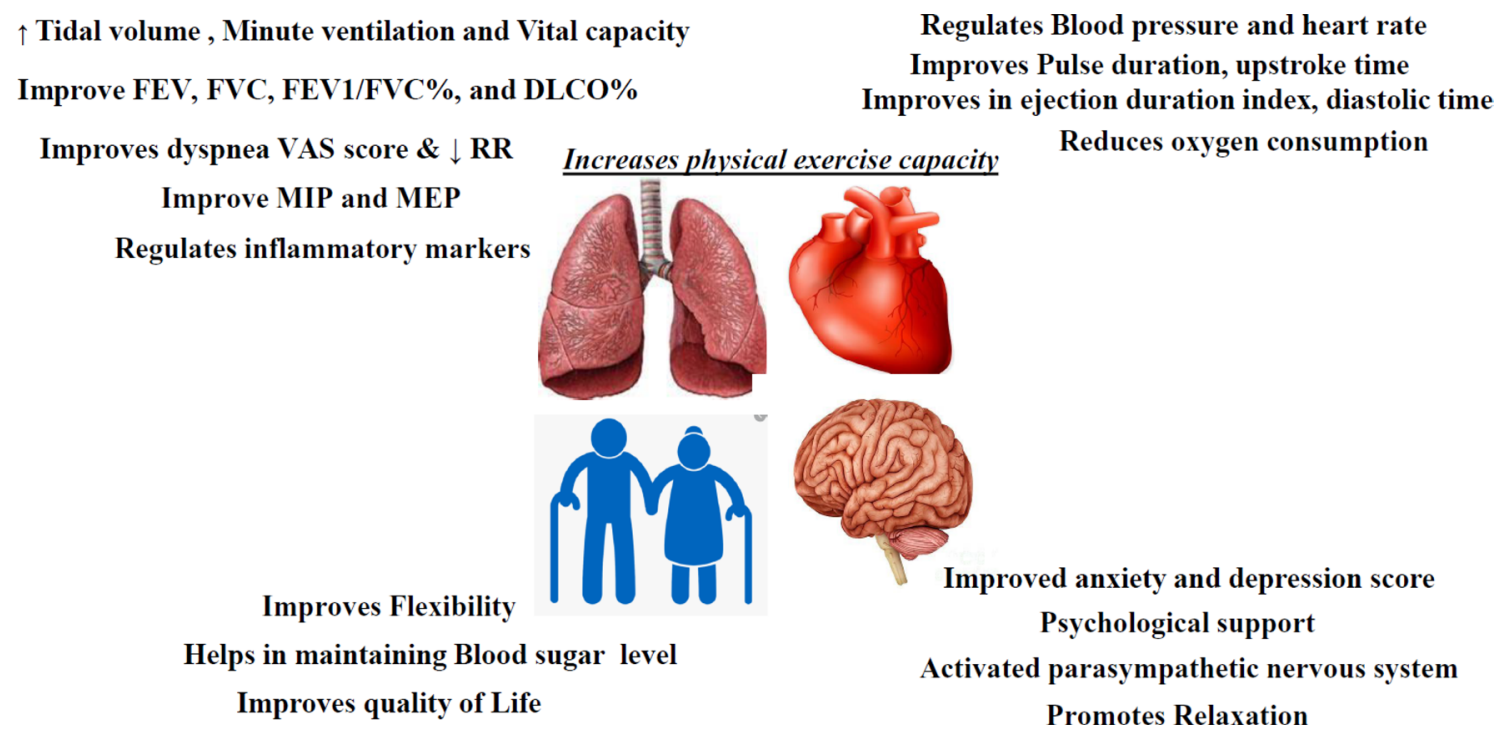

Fig. 4 Schematics representation of post-COVID-19 rehabilitation and Yoga. Figure shows post COVID-19 utility of Yoga in cardiopulmonary, mental, and co-morbidities rehabilitation

Fig. 5 AYUSH guideline can help to get back, keep, or improve the functioning system of the body as a standard rehabilitation therapy through routine procedures, meditation, Pranayama, herbs, and Asanas

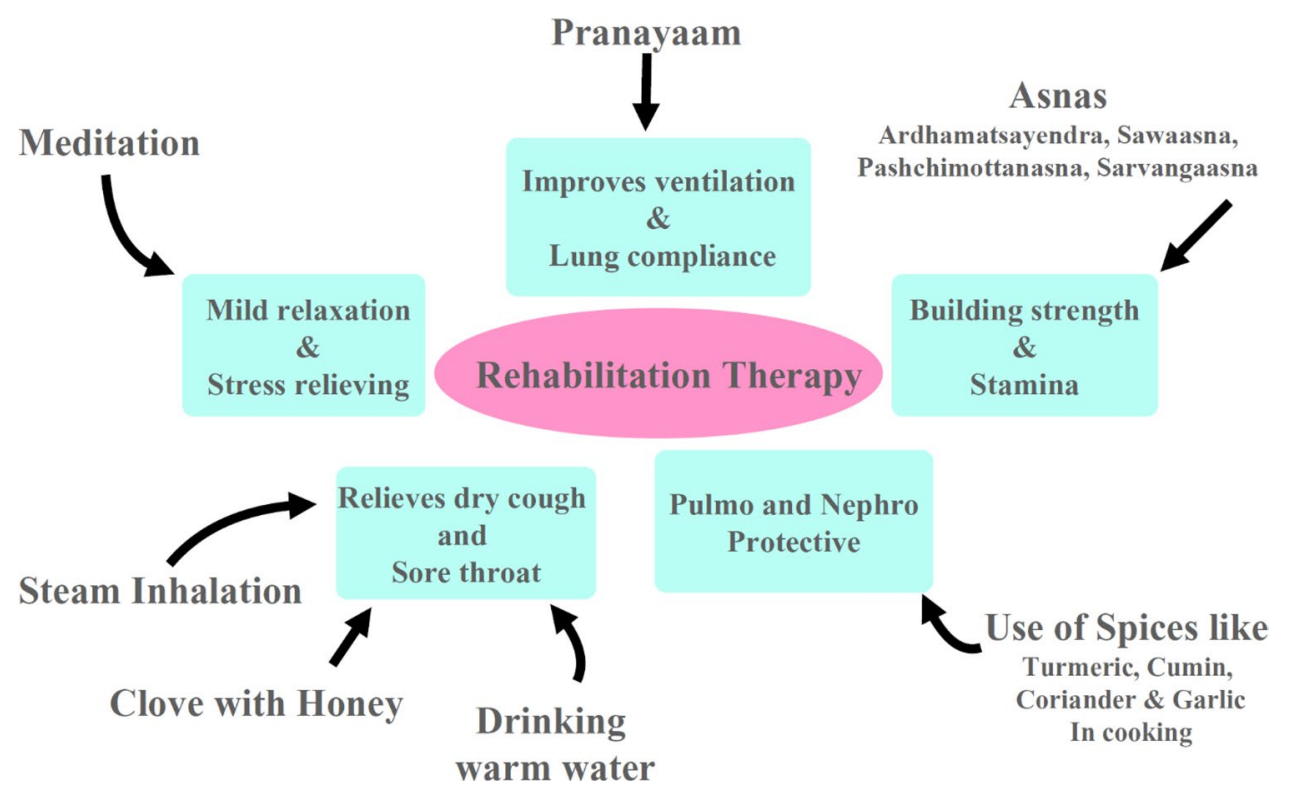

warm water the modern medical fraternities have some apprehension for the unconventional method like AYUSH. The information discussed in this article is the rationale behind advisory and will gradually increase the wisdom to provide an alternative to a large Indian community. The detailed immunological and other scenarios of herbal medicine are portrayed in Fig. 1a in terms of B-cell/T-cell response, cytokines release, and antimicrobial activity. It can be concluded that AYUSH-advised herbs and Yoga promote the state of immunity preparedness to threat, and equipoise the immunity in COVID-19, COVID-19 related co-morbidities (Fig. 2) and stress management. It may be a simple, safe, cost-effective, accessible, acceptable, infrastructure compatible, pragmatic for a longer duration, and sustainable preventive and prophylaxis approach for COVID-19. AYUSH ministry advisory not only supports the health of COVID-19 people but also creating a mental state that one can remain safe following home remedies (Rajkumar 2020). It is adoptive in nature and in the long run, it will change an individual's habits that may reduce the burden of overall health care. It was an advisory release for pan India which may have a pan globe following. We have thoroughly searched the scientific domain for each component of advisory for its pharmacological relevance. We conclude 
that this advisory comes up with a strong scientific rationale and further indicated more precise research in clinical/ observational trials concerning COVID-19 and prevention of other infections. This advisory can pave the way to overcome this pandemic and may open a new window for the effective use of traditional medicines throughout the world. Considering the properties of flora, Yoga, and procedures, this advisory encouraging us to get closer to the natural way of healing.

Acknowledgements Authors are thankful to their parent institutions for the support and assistance during the work and scientific writing. We acknowledge Dr. Kathrina Petterson Sjorup, World Health Organisation, Uppsala Monitoring System, Sweden for giving guidance of public access website www.vigiaccess.org. We thank Prof. Brij Mohan Singh \& Prof. Kishor Patwardhan, Banaras Hindu University, Varanasi, India for guiding and conceptual structuring. We thank Dr. Neelam Singh, Research Officer, CCRAS, Gwalior, India for information about Ayush Sanjivani mobile application. Authors are thankful to their parent institutions for providing all kind of support. The authors have no financing to disclose.

\section{Declarations}

Ethical Statement This article does not contain any studies involving animals performed by any of the authors. This article does not contain any studies involving human participants performed by any of the authors.

Conflict of interest Prashant Kumar Gupta, Kishor Sonewane, Mariappan Rajan, Nitin J Patil, Trapti Agrawal, Ena Ray Banerjee, Nagendra Singh Chauhan, Awanish Kumar declare that they have no conflict of interest.

\section{References}

Abdel-Tawwab M, Samir F, Abd El-Naby AS, Monier MN (2018) Antioxidative and immunostimulatory effect of dietary cinnamon nanoparticles on the performance of Nile tilapia, Oreochromis niloticus (L.) and its susceptibility to hypoxia stress and Aeromonas hydrophila infection. Fish Shellfish Immunol 74:19-25

Afolayan FID, Erinwusi B, Oyeyemi OT (2018) Immunomodulatory activity of curcumin-entrapped poly D, L-lactic-co-glycolic acid nanoparticles in mice. Integr Med Res 7:I68-I75

Agbaje EO, Adeneye AA, Daramola AO (2009) Biochemical and toxicological studies of aqueous extract of Syzigiumaromaticum (L) merr. \&perry(Myrtaceae) in rodents. Afr J Tradit Complement Altern Med 6(3):241-254

Ahmad A, Husain A, Mujeeb M (2013) A review on therapeutic potential of Nigella sativa: a miracle herb. Asian Pac J Trop Biomed 3(5):337-352

Ahmad RA, Nouri HS, Majid FAA et al (2015) Assessment of potential toxicological effects of Cinnamon bark aqueous extract in rats. Int J Biosci Biochem Bioinformatic 5(1):36-44

Al-Ankari AS (2005) Immunomodulating effects of black seed and oxytetracycline in pigeons. Immunopharmacol Immunotoxicol 27:515-520

Anonymous (2020) Order no. F.no. Z 25023/09/2018-2020-DCC (AYUSH), Government of India, Ministry of AYUSH
Arora S, Bhattacharjee J (2008) Modulation of immune responses in stress by Yoga. Int J Yoga 1(2):45-55

Arreola R, Quintero-Fabian S, Lopez-Roa RI et al (2015) Immunomodulation and anti-inflammatory effects of garlic compounds. J Immunol Res 2015:401630

Atkinson NL, Permuth-Levine R (2009) Benefits, barriers, and cues to action of yoga practice: a focus group approach. Am J Health Behav 33(1):3-14

Balasubramaniam M, Telles S, Doraiswamy PM (2013) Yoga on our minds: a systematic review of yoga for neuropsychiatric disorders. Front Psychiatry 3:117

Bale AP, Manerikar V, Tengse VG (2015) Review on pharmacodynamics of nasya. Int Ayu Med J 3(6):1780-1784

Bastaki M, Aubanel M, Cachet T (2018) Absence of adverse effects following the gavage administration of methyl propyl trisulfide to Sprague-Dawley rats for 90 days. Food Chem Toxicol 120:544-551

Bezerra LA, De Melo HF, Garay AP et al (2014) Do 12-week yoga program influence respiratory function of elderly women? J Hum Kinet 43:177-184

Bhardwaj A, Sharma MK, Gupta M (2013) Endoscopic evaluation of therapeutic effects of "Anuloma-Viloma Pranayama" in Pratishyayaw.s.r. to mucociliary clearance mechanism and Bernoulli's principle. Ayu 34(4):361-367

Byadgi PS (2011) Concept of immunity in Ayurveda. J Appl Pharm Sci 1(5):21-24

Cabral P, Meyer HB, Ames D (2011) Effectiveness of yoga therapy as a complementary treatment for major psychiatric disorders: a meta-analysis. Prim Care Companion CNS Disord 13(4):PCC.10r1068

Carrasco FR, Schmidt G, Romero AL et al (2009) Immunomodulatory activity of Zingiber officinale Roscoe, Salvia officinalis L. and Syzygiumaromaticum L. essential oils: evidence for humor- and cell-mediated responses. J Pharm Pharmacol 61(7):961-967

Chandrasekaran CV, Sundarajan K, Edwin JR, Gururaja GM, Mundkinajeddu D, Agarwal A (2013) Immune-stimulatory and antiinflammatory activities of Curcuma longa extract and its polysaccharide fraction. Phcog Res 5:71-79

Chauhan PS, Satti NK, Suri KA, Amina M, Bani S (2010) Stimulatory effects of Cuminum cyminum and flavonoid glycoside on cyclosporine-A and restraint stress induced immune-suppression in Swiss albino mice. Chem Biol Interact 185(1):66-72

Chouhan G, Islamuddin M, Muzamil YW (2015) Leishmanicidal activity of Piper nigrum bioactive fractions is interceded via apoptosis in vitro and substantiated by Th1 immunostimulatory potential in vivo. Front Microbiol 6:1368

Ciavarella C, Motta I, Valente S, Pasquinelli G (2020) Pharmacological (or synthetic) and nutritional agonists of PPAR- $\gamma$ as candidates for cytokine storm modulation in COVID-19 disease. Molecules 25(9):2076

Das R, Mitra S, Mukherjee K, Paul P, Singh UP, Banerjee E (2015) Anti-oxidant and anti-inflammatory activities of different varieties of piper leaf extracts (Piper betle L.). OMICS Nutr Food Sci 5:5

Das R, Biswas S, Banerjee E (2016) Nutraceutical—prophylactic and therapeutic role of functional food in health and disease. J Nutr Food Sci 6:4

Devpura G, Tomar BS, Nathiya D et al (2021) Randomised placebocontrolled pilot clinical trials on the efficacy of Ayurvedic treatment regime on COVID-19 positive patients. Phytomedicine 4:84

Duncker SC, Philippe D, Martin-Paschoud C et al (2012) Nigella sativa (black cumin) seed extract alleviates symptoms of allergic diarrhea in mice, involving opioid receptors. PLoS ONE 7:e39841

Dugenci SK, Arda N, Candan A (2003) Some medicinal plants as immunostimulant for fish. J Ethnopharmacol 88(1):99-106 
Elmowalid GA, AbdEl-Hamid MI, AbdEl-Wahab AM et al (2019) Garlic and ginger extracts modulated broiler chicks innate immune responses and enhanced multidrug resistant Escherichia coli $\mathrm{O} 78$ clearance. Comp Immunol Microbiol Infect Dis 66:101334

Falkenberg RI, Eising C, Peters ML (2018) Yoga and immune system functioning: a systematic review of randomized controlled trials. J Behav Med 41(4):467-482

Feng ZH, Zhang GM, Hao TL et al (1994) Effect of diallyl trisulfde on the activation of $\mathrm{T}$ cell and macrophage-mediated cytotoxicity. $\mathrm{J}$ Tongji Med Univ 14:142-147

Flores GA, Rodriguez VL, Licea QR, Guerra TP, Padilla RC (2008) In vitro lymphocyte proliferation induced by Ocimumbasilicum, Perseaamericana, Plantago virginica and Rosa spp. extracts. J Med Plants Res 2(1):5-10

Gautam MK, Goel RK (2014) Toxicological study of Ocimum sanctum Linn leaves: hematological, biochemical, and histopathological studies. J Toxicol 2014:135654

Ghonime M, Eldomany R, Abdelaziz A, Soliman H (2011) Evaluation of immunomodulatory effect of three herbal plants growing in Egypt. Immunopharmacol Immunotoxicol 33:141-145

Godse AS, Shejwal BR, Godse AA (2015) Effects of suryanamaskar on relaxation among college students with high stress in Pune, India. Int J Yoga 8(1):15-21

Guleria R, Arora S, Mohan A et al (2015) Yoga is as effective as standard pulmonary rehabilitation in improving dyspnea, inflammatory markers, and quality of life in patients with COPD. Chest J 148(4):907A. https://doi.org/10.1378/chest. 2266469

Gupta A, Gupta R, Sood S et al (2014) Pranayam for treatment of chronic obstructive pulmonary disease: results from a randomized controlled trial. Integr Med (Encinitas) 13(1):26-31

Hesam H, Qotbi AAA, Seidavi A, Norris D (2014) Effects of different levels of coriander (Coriandrum sativum) seed powder and extract on serum biochemical parameters, microbiota, and immunity in broiler chick. Sci World J 2014:628979

Hooda R, Hooda S, Sharma R (2017) Oil pulling: a wonderful ayurvedic Therapy. Int J Pharmacogn Chin Med 1(2):000112

https://ayush.gov.in

Ingok AM, Guler FK (2017) Cardamom, cumin, and Dill weed essential oils: chemical compositions, antimicrobial activitities, and mechanisms of action against Campylobacter spp. Molecules 22(7):1191

Jeba RC, Vaidyanathan R, Rameshkumar G (2011) Immunomodulatory activity of aqueous extract of Ocimum sanctum in rat. Int J Pharm Biomed Res (IJPBR) 2(1):33-38

Jia Xu, Yunfei Z (2020) Traditional Chinese Medicine treatment of COVID-19. Complement Ther Clin Pract 39:101165

Kamble UP (2019) Awareness of yoga develops human capital. Int J Physio Nutr Phys Educ 4(1):1348-1350

Kar S, Konsam S, Hore G, Mitra S, Biswas S, Sinha AB, Jana NR, Banerjee E (2015) E. Therapeutic use of fisetin, curcumin, and mesoporous carbaon nanoparticle loaded fisetin in bleomycin-induced idiopathic pulmonary fibrosis. Biomed Res Ther 2(4):250-262

Kesavan M, Rajagopalan K, Kuttan G, Kuttan R (1998) Clinical evaluation for the efficacy of an Ayurvedic drug formulation against HIV and AIDS. Amala Res Bull 18:117

Khedkar W, Pankaj SG et al (2020) A prospective clinical study of an Ayurvedic regimen in COVID-19 patients. J Ayurveda Integr Med. https://doi.org/10.1016/j.jaim.2020.10.008

Kim DH, Lee HG, Choi JM (2019) Curcumin elevates T follicular helper cells and germinal center B cell response for antibody production in mice. Immune Netw 19(5):e35

Kittima V, Nontawith A, Ngampong K et al (2010) Immunological and bactericidal effects of turmeric (Curcuma longa Linn.) extract in Pacific white shrimps (Litopenaeusvannamei Boone). Kasetsart J. (Nat. Sci.) 44:850-858
Krishnaraju AV, Sundararaju D, Sengupta K et al (2009) Safety and toxicolocal evaluation of Demethylated curcuminoids; A novel standardized curcumin product. Toxicol Mech Methods 19(6-7):447-460

Kupershmidt S, Barnable T (2019) Definition of a Yoga breathing (Pranayama) protocol that improves lung function. Holist Nurs Pract 33(4):197-203

Larypoor M, Bayat M, Zuhair MH et al (2013) Evaluation of the number of CD4(+) CD25(+) FoxP3(+) treg cells in normal mice exposed to AFB1 and treated with aged garlic extract. Cell J 15:37-44

Lin A, Hye WL et al (2020) Herbal medicine and pattern identification for treating COVID-19: a rapid review of guidelines. Integr Med Res 9(2):100407. https://doi.org/10.1016/j.imr. 2020.100407

Liu K, Zhang W, Yang Y et al (2020) Respiratory rehabilitation in elderly patients with COVID-19: a randomized controlled study. Complement Ther Clin Pract 39:101166

Madaan A, SatyajyotiKanjilal AG et al (2015) Evaluation of immunostimulatory activity of Chyawanprash using in vitro assays. Indian J Exp Biol 53:158-163

Mandal S, Mandal M (2015) Coriander (Coriandrum sativum L.) essential oil: chemistry and biological activity. Asian Pac J Trop Biomed 5(6):421-428

Masoud ZS, Mohammad A, Leila E (2014) Biological activities of a new antimicrobial peptide from Coriandrum sativum. Int J Biosci 4(6):89-99

Masram P, Chaudhary S, Patel KS (2014) A brief review on ayurvedic concept of immunity and immunization. Ayurpharm Int J Ayur Alli Sci 3:230-240

Maurya VK, Kumar S, Prasad AK et al (2020) Structure-based drug designing for potential antiviral activity of selected natural products from Ayurveda against SARS-CoV-2 spike glycoprotein and its cellular receptor. Virus Dis. https://doi.org/10.1007/ s13337-020-00598-8

McCall MC, Ward A, Roberts NW, Heneghan C (2013) Overview of systematic reviews: yoga as a therapeutic intervention for adults with acute and chronic health conditions. Evid Based Complement Alternat Med 2013:945895. https://doi.org/10.1155/2013/ 945895

Mediratta PK, Sharma KK, Singh S (2002) Evaluation of immunomodulatory potential of Ocimum sanctum seed oil and its possible mechanism of action. J Ethnopharmacol 80:15-20

Mukherjee N, Dash PK, Ram GC (2005) Immunotherapeutic potential of ocimum sanctum (L) in bovine subclinical mastitis. Res Vet Sci 79:37-43

Mukherjee PK, Bahadur S, Harwansh RK et al (2017) Paradigm shift in natural product research: traditional medicine inspired approaches. Phytochem Rev 16:803-826

Neelam LD, Nilofer SN (2010) Preliminary immunomodulatory activity of aqueous and ethanolic leaves extracts of Ocimum basilicum Linn in mice. Int J PharmTech Res 2(2):1342-1349

Nonaka M, Yamashita K, Lizuka Y et al (1997) Effects of dietary sesaminol and sesamin on eicosanoid production and immunoglobulin level in rats given ethanol. Biosci Biotechnol Biochem 61:836-839

Ornish D, Lin J, Daubenmier J et al (2008) Increased telomerase activity and comprehensive lifestyle changes: a pilot study. Lancet Oncol 9(11):1048-1057

Pandkar DP, Sachdeva V (2020) Pathophysiology of COVID-19 and host centric approach of Ayurveda. J Ayurveda Integr Med. https://doi.org/10.1016/j.jaim.2020.11.010

Pan MH, Wu JH, Ho CT (2017) Effects of water extract of curcuma longa (L.) roots on immunity and telomerase function. J Compl Intgr Med 2017:20150107 
Park SJ, Lee D, Lee M et al (2018) The effects of Curcuma longa L., Purple sweet potato, and the mixtures of the two on immunomodulation in C57BL/6J mice infected with LP-BM5 murine leukemia retrovirus. J Med Food 2018:1-2

Patel DK, Desai SN, Devkar R et al (2012) Acute and sub-chronic toxicological evaluation of hydro-methanolic extract of Coriandrum sativum L. seeds. EXCLI J 11:566-575

Patil SG (2016) Abstract P161: effect of Yoga program on cardiovascular function in elderly with stage I hypertension. Circulation 133:AP161

Paul P, Majhi S, Mitra S, Banerjee E (2018) Immuno-modulatory and therapeutic effect of curcumin in an allergen-sensitized murine model of chronic asthma. J Clin Cell Immunol 9:3

Peedikayil FC, Sreenivasan P, Narayanan A (2015) Effect of coconut oil in plaque related gingivitis - a preliminary report. Niger Med J 56(2):143-147

Prasad VV (2002) Sushruta Samhita, Dalhana Nibandhasangraha; Sutra Sthana, chapter no. 1, verse no. 27

Priya R, Sujatha V (2020) AYUSH for COVID-19: science or superstition? Indian J Public Health 64:S105-S107

Puri A, Sahai R, Singh KL, Saxena RP, Tandon JS, Saxena KC (2000) Immunostimulant activity of dry fruits and plant materials used in indian traditional medical system for mothers after child birth. J Ethnopharmacol 71(1-2):89-92

Rajkumar RP (2020) Ayurveda and COVID-19: Where psychoneuroimmunology and the meaning response meet. Brain Behav Immun S0889-1591(20):30637-30641

Rangnekar H, Patankar S, Suryawanshi K et al (2020) Safety and efficacy of herbal extracts to restore respiratory health and improve innate immunity in COVID-19 positive patients with mild to moderate severity: a structured summery of a study protocol for a randomised controlled trial. Trial 21(1):943

Rastogi S, Pandey DN, Singh RH (2020) COVID-19 pandemic: a pragmatic plan for Ayurveda intervention. J Ayu Integr Med. https:// doi.org/10.1016/j.jaim.2020.04.002

Rodrigo C, Fernando SD, Rajapakse S et al (2020) Clinical evidence for repurposing chloroquine and hydroxychloroquine as antiviral agents: a systematic review. Clin Microbiol Infect. https://doi. org/10.1016/j.cmi.2020.05.016

Rong X, Peng G, Suzuki T et al (2009) A 35-day gavage safety assessment of ginger in rats. Regul Toxicol Pharmacol 54(2):118-123

Saketkhoo K, Januszkiewicz A, Sackner MA (1978) Effects of drinking hot water, cold water, and chicken soup on nasal mucus velocity and nasal airflow resistance. Chest 74(4):408-410

Sastry JLN, Gupta A, Brindavanam NB et al (2014) Quantification of immunity status of Dabur chyawanprash-a review part-1 (experimental studies). Indian J Appl Res 4:20-24

Segerstrom SC, Miller GE (2004) Psychological stress and the human immune system: a meta-analytic study of 30 years of inquiry. Psychol Bull 130(4):601-130

Sezgin Y, Ozgul BM, Alptekin NO (2019) Efficacy of oil pulling therapy with coconut oil on four-day supragingival plaque growth: a randomized crossover clinical trial. Complement Ther Med 47:102193

Sengupta P (2012) Health impacts of yoga and pranayama: a state-ofthe-art review. Int J Prev Med 3(7):444-458

Shan BE, Yoshida Y, Sugiura T, Yamashita U (1999) Stimulating activity of Chinese medicinal herbs on human lymphocytes in-vitro. Int J Immunopharmacol 21:149-159

Sharma N, Jacob D (2001) Antifertility investigation and toxicological screening of the petroleum ether extract of the leaves of Mentha arvensis L. in male albino mice. J Ethnopharmacol 75(1):5-12

Shete SU, Verma A, Kulkarni DD et al (2017) (2017) Effect of yoga training on inflammatory cytokines and $\mathrm{C}$-reactive protein in employees of small-scale industries. J Educ Health Promot 6:76
Siddiqui MJ, Aslam A, Khan T (2019) Comparison and evaluation of different seed extracts of Trachyspermum ammi for immunomodulatory effect on cell-mediated immunity through delayed-type hypersensitivity assay skin thickness method. J Pharm Bioallied Sci 11(1):43-48

Siharat C, Nirush L, Umarat S et al (2007) Acute and subchronic toxicity study of the water extract from drid fruits of Piper nigrum L. in rats. Songklanakarin J Sci Tech 29(1):109-124

Singh VP, Khandelwal B, Sherpa NT (2015) Psycho-neuro-endocrineimmune mechanisms of action of yoga in type II diabetes. Anc Sci Life 35(1):12-17. https://doi.org/10.4103/0257-7941.165623 (PMID: 26600662)

Singh AK, Gupta R, Misra A (2020) Comorbidities in COVID-19: outcomes in hypertensive cohort and controversies with renin angiotensin system blockers. Diabetes Metab Syndr 14(2):283-287

Shruthi RR, Venkatesh Y, Muralikrishna G (2017) In vitro immunomodulatory potential of macromolecular components derived from the aqueous extract of ajowan [Trachyspermumammi (L.) Sprague]. Indian J Tradit Knowl 16:506-513

Srinivasan K (2018) Cumin (Cuminum cyminum) and black cumin (Nigella sativa) seeds: traditional uses, chemical constituents, and nutraceutical effects. Food Qual Saf 00:1-16

Stephens I (2017) Medical yoga therapy. Children (Basel) 4(2):12

Tabassum I, Siddiqui ZN, Rizvi SJ (2010) Effects of Ocimum sanctum and Camellia sinensis on stress-induced anxiety and depression in male albino Rattus norvegicus. Indian J Pharmacol 42(5):283-288

Taghizadeh M, Ostad SN, Asemi Z et al (2017) Sub-chronic oral toxicity of Cuminumcyminum L's essential oil in female wistarrats. Regul Toxicol Pharmacol 88:138-143

Taliaz D, Loya A, Gersner R et al (2011) Resilience to chronic stress is mediated by hippocampal brain-derived neurotrophic factor. $\mathrm{J}$ Neurosci 31(12):4475-4483

Thirthalli J, Naveen GH, Rao MG et al (2013) Cortisol and antidepressant effects of yoga. Indian J Psychiatry 55(Suppl 3):S405-S408

Tillu G, Chaturvedi S, Chopra A, Patwardhan B (2020) Public health approach of Ayurveda and yoga for COVID-19 prophylaxis. J Altern Complement Med 26(5):360-364

Trikam Y, Sharma NK (2002) Bhanumati commentary by Chaktapani Datt on Sushruta Samhita sutra sthana, Krishna Das Academy, Varanasi

Tyagi A (2013) Oxygen consumption changes with yoga practices: a systematic review. https://doi.org/10.1177/2156587213492770

Umasankar K, Nambikkairaj B (2018) Effects on the selected herbal plant Syzygium aromaticum flower buds oil of immunomodulatory activity in Albino Wistar Rats. Int J Sci Res 7(7):1139-1144

Vaidya Y, Trikamji A (2004) Charak Samhita, Viaman Sthana Chapter 3 , page 246 , verse no 40

Weishun T, Akanda MR, Islam A (2018) The anti-stress effect of Mentha arvensis in immobilized rats. Int J Mol Sci 19(2):355

Woodyard C (2011) Exploring the therapeutic effects of yoga and its ability to increase quality of life. Int J Yoga 4(2):49-54

Wren AF, Cleary M, Frantz C et al (2002) 90 day oral toxicity study of a grape seed extract (IH636) in rats. J Agric Food Chem 50(7):2180-2192

www.ayushsuraksha.com

www.vigiaccess.org

Yang J, Zhou Y (2020) Prevalence of comorbidities and its effects in patients infected with SARS-CoV-2: a systematic review and meta-analysis. Int J Infect Dis 94:91-95

Publisher's Note Springer Nature remains neutral with regard to jurisdictional claims in published maps and institutional affiliations. 